\title{
Ržanovo Metamorphosed Lateritic Fe-Ni Deposit, Republic of Macedonia
}

\author{
T. Serafimovski ${ }^{a}$, A. V. Volkov ${ }^{b}$, B. Boev ${ }^{a}$, and G. Tasev \\ ${ }^{a}$ Faculty of Mining and Geology, Goce Delčev University, Štip, Republic of Macedonia \\ ${ }^{b}$ Institute of Geology of Ore Deposits, Petrography, Mineralogy, and Geochemistry, Russian Academy of Sciences, Staromonetnyi \\ per. 35, Moscow, 119017 Russia \\ Received January 10, 2013
}

\begin{abstract}
The Ržanovo deposit is a unique example of metamorphosed lateritic $\mathrm{Fe}-\mathrm{Ni}$ deposits in the wellknown Vardar ophiolitic belt of the Balkans, where Fe-Ni mineralization is a product of the Early Cretaceous lateritic weathering mantle after Jurassic ultramafic rocks subsequently redeposited into the Cretaceous shallow-water marine basin. As a result, a layer of $\mathrm{Fe}-\mathrm{Ni}$ ore $30-50 \mathrm{~m}$ thick with an average Ni grade of $\sim 1 \%$ was formed at the Ržanovo deposit; this layer is traced for more than $4 \mathrm{~km}$ along the strike and $500 \mathrm{~m}$ down the dip. At the end of the Late Cretaceous, intense Alpine tectonic faulting and folding resulted in overturning of the initially horizontal ore layer, which is now nearly vertical. The most abundant fissile hematite ore contains $0.70-1.27 \% \mathrm{Ni}$, whereas the economically most important massive hematite ore with $0.93-1.49 \% \mathrm{Ni}$ occurs locally. The major $\mathrm{Ni}$-bearing minerals are magnetite, hematite, chromite, sulfides, talc, chlorite, amphibole, and stilpnomelane.
\end{abstract}

DOI: $10.1134 / \mathrm{S} 1075701513050073$

\section{INTRODUCTION}

The Ržanovo deposit was discovered in 1952. Prospecting and exploration started in 1956 and continued until 1972. The Ržanovo Mine has worked with small breaks for more than 30 years. Its design output is $534 \mathrm{kt}$ ore per year. About 11.2 Mt ore with an average grade of $0.92-0.94 \% \mathrm{Ni}$ has mined since 1980 until now. The design depth of the open pit is 750 m.a.s.l. Ore is currently mined at 775-760 m.a.s.l. Thus, about $2 \mathrm{Mt}$ of ore have been left for open cast mining. This amount is sufficient for 3-4 years of operations at the mine and the metallurgical combine.

The deposit is located in mountain terrain, and the metallurgical combine is situated $40 \mathrm{~km}$ to the northwest in the wide Vardar River valley behind the mountain range near the town of Kavadarci. The ore is transported from the Ržanovo Mine over the range by belt conveyer (Fig. 1). This is one of the longest conveyers in the world.

The ultimate production of the metallurgical combine is $\mathrm{Fe}-\mathrm{Ni}$ alloy $(20 \% \mathrm{Ni}, 80 \% \mathrm{Fe})$, which is produced by joint melting of silicate Ni ore imported from $\mathrm{New}$ Caledonia and Indonesia and $\mathrm{Fe}-\mathrm{Ni}$ ore mined from the Ržanovo deposit.

In recent years, to prolong the lifetime of the mine and to provide the metallurgical combine with ore, detailed geological exploration has been carried out at deep levels. The reserve growth amounted to $\sim 5 \mathrm{Mt}$

Corresponding author: A.V. Volkov. E-mail: alexandr@igem.ru with an average grade of $1.02 \% \mathrm{Ni}$, which will be enough to prolong mining for 10-12 years.

The exploitation of the Ržanovo Mine was accompanied by scientific research (Ivanov, 1962, 1965; Maksimovic and Panto, 1982; Boev, 1982; Boev and Stojanov, 1985; Boev and Lepitkova, 1994; Boev and Serafimovski, 1992, 1996; Boev and Jankovic, 1996).

After 16 years of waning scientific interest in the Ržanovo deposit and, correspondingly, a decline in publications, this paper presents up-to-date results of mineralogical and geochemical studies of various ore types from this deposit.

During fieldwork, about 100 samples of ores and host rocks were collected from the Ržanovo open pit. All samples were preliminarily prepared at the laboratory for petrographic examinationl mineralogical, microprobe, X-ray diffraction, and chemical analyses; and ICP-AES.

Minerals were analyzed at BRGM, Orleans, France, on a Cameca SX 50 microprobe equipped with five spectrometers and a BSE detector; it operated at $20 \mathrm{keV}$ and $20 \mathrm{nA}$; the sampling interval was $10 \mathrm{~s}$ for each element. Analytical standards were used to determine the corresponding elements. The results were processed with Quanti Tool 3.6. Chemical, X-ray diffraction, and ICP-AES analyses were carried out at the Royal Holloway College, London University, Great Britain. Mineralogical analysis was performed at the laboratory of the Faculty of Mining and Geology, Goce Delčev University, Stip, Republic of Macedonia. 


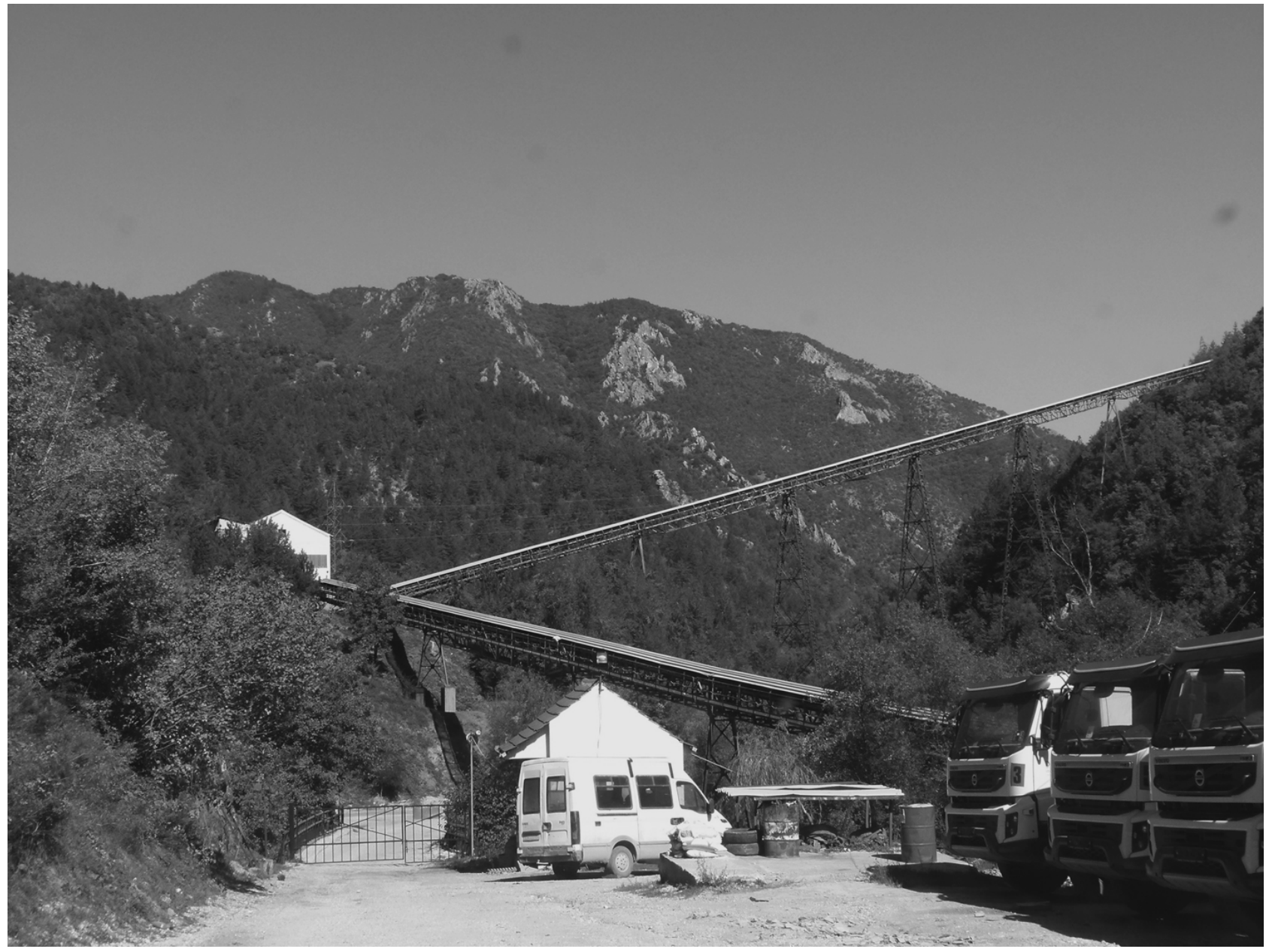

Fig. 1. Belt conveyer for transport of ore from Ržanovo Mine to metallurgical combine near town of Kavadarci. Photo by A.V. Volkov.

\section{TECTONIC POSITION OF AREA IN VICINITY OF DEPOSIT}

The Macedonian ophiolitic complex is an essential part of the eastern Mediterranean, a region with one of the world's largest concentration of ophiolites. Most Jurassic ophiolites in this region belong to the Oman suprasubduction type (Robertson, 2006; Dilek and Thay, 2009).

In terms of plate tectonics, the leading role in the regional architecture is played by the Tethys paleoocean and sutures left at the place of the reworked oceanic crust. Remnants of the oceanic crust related to the Vardar Suture and a number of pre-Alpine (Precambrian and Paleozoic) fragments alternating with Alpine sedimentary formations are predominant in the Alpine structure of Macedonia and Bulgaria (Zagorchev et al., 2008).

Remnants of the Tethian oceanic crust in the Balkan region are composed of ophiolitic sheets consisting of lherzolite, harzburgite, dunite, and basaltic pillow lavas, which are the most abundant in the south- ern Vardar Zone, where they locally alternate with thrust sheets of Triassic and Jurassic sedimentary rocks deposited on the continental slope. The Jurassic peridotites and weathering mantles developed after them are of special importance for the formation of Ni-silicate and $\mathrm{Fe}-\mathrm{Ni}$ deposits. The ophiolites make up the western belt in the inner Albanides (Mirdité Zone) and the eastern belt along the Vardar Zone (Fig. 2).

Many geologists assume that they belong to independent tectonic units, which were formed close to the continental margin in the Late and Early Cretaceous. These belts extend almost parallel to each other. Their spatial position and the same orientation are interpreted in alternative terms. According to one rather sound hypothesis, these belts are remnants of two independent Tethian oceans. The alternative concept assumes that ophiolites of the Mirdité Zone correspond to the compressed imbricate part of the Vardar Suture overthrust westward. The upper chronological limit of the ocean is determined by the Kimmeridgian-Tithonian carbonate rocks with calpionellides (Ivanov et al., 1987). 


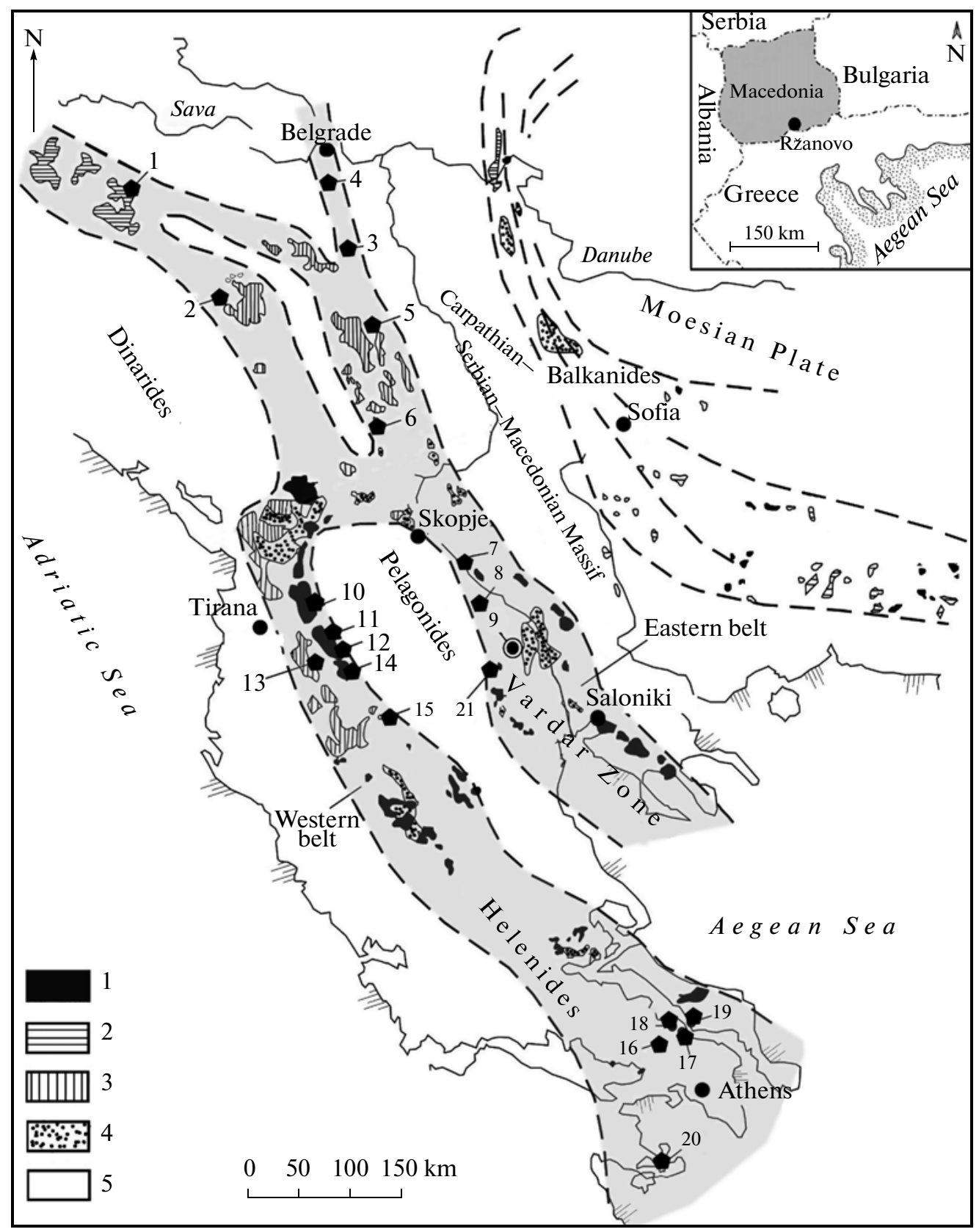

Fig. 2. Location of main deposits and occurrences of Ni-silicate and Ni-bearing iron ores in west and east of ophiolitic belt in southeastern Europe, after Boev and Jankovic (1996). Ophiolitic belts are shown by dashed lines and gray color. (1) Dunite and harzburgite, (2) harzburgite, (3) lherzolite, (4) sedimentary rocks and pillow lavas, (5) other rocks. Ni-silicate and Ni-bearing iron (numbers in figure): 1, Konjuh (Co, Ni, Fe); 2, Mokra Gora (Fe-Ni); 3, Lipovak (Fe-Ni); 4, Ba (Ni-silicate); 5, Veluc (Ni); 6, Glogovac (Ni); 7, Glavica (Ni); 8, Veles-Klera (Fe-Ni); 9, Ržanovo (Fe-Ni); 10, Kukés (Fe-Ni); 11, Piskas (Fe-Ni); 12 , Bustrak (Fe-Ni); 13, Gumaz (Fe-Ni); 14, Gurii Kuk (Fe-Ni); 15, Bilic (Fe-Ni); 16, Heronia (Fe-Ni); 17, Beotia $(\mathrm{Fe}-\mathrm{Ni})$; 18, Larymna (Fe-Ni); 19, Central Eboia (Fe-Ni); 20, Argolis (Fe-Ni); 21. Almopilas (Fe-Ni).

The obduction probably continued for $15-30 \mathrm{Ma}$ from the formation of ophiolites to subsequent thrusting over the continental margin. By the way, it is assumed that the northeastern subduction of the oceanic plate beneath the Serbian-Macedonian Massif continued in the Cretaceous and even left trails in the Paleogene tectonic evolution.
In the Late Jurassic, the closure of the Vardar ocean gave way to a short period of subduction with formation of oceanic crust and development of granitic magmatism. This stage completed by young Kimmerian Orogeny (collision at the end of Late Jurassic and largely in the Early Cretaceous) and creation of continental conditions in the Vardar Zone. Tectonic move- 
ments were expressed as folding, faulting, breakdown, and imbrication of Jurassic and pre-Jurassic rocks (Robertson et al., 2009; Zagorchev et al., 2012).

The compression of the western subzone of the Vardar Zone led to protrusion and origination of the NW-SE-trending belts of ophiolitic tectonites, which were weathered under continental conditions with formation of lateritic weathering mantles. The latter were redeposited in the Albian-Cenomanin-Turonian together with terrigenous sediments; as a result, oolitic $\mathrm{Fe}-\mathrm{Ni}-\mathrm{Co}$ ores were formed.

Thus, the Vardar Zone-a complex tectonic block between the Serbian-Macedonian Massif in the east and the Dinarides and Helenides in the west-played the crucial role in the origination and spatial distribution of the Jurassic ophiolitic complexes and related $\mathrm{Fe}-\mathrm{Ni}$ deposits in the southern part of Balkan Peninsula (Fig. 2). This is a belt more than $1000 \mathrm{~km}$ long and 60-80 km wide, which extends in the NW-SE direction to the north of Belgrarde via Serbia and Macedonia toward the Aegean Sea in northern Greece, where it plunges and turns east as a segment of the Izmir-Ankara Zone.

The Ržanovo (Ržanovo-Studena-Voda) depositone of the largest lateritic $\mathrm{Fe}-\mathrm{Ni}$ deposits in the Vardar Zone-is situated near the Macedonian-Greece state border (Fig.2) in the western subzone of ophiolitic belt of the Vardar Zone, which consists of several lithostratons different in mineralogy and petrology of rocks and specific geological history.

The Precambrian albitic gneisses with sporadic amphibolite lenses and marble blocks are the oldest in this area. Paleozoic schist, phyllite, metasandstone, shale, and quartzite occur locally. Widespread Triassic sedimentary rocks comprise two main facies: (1) marmorized limestone and dolomite and (2) claystone and sandstone with sporadic inclusions of dolerite and greenschist. The Jurassic sequences consist of limestone, sandstone, shale, quartzite, and chert associated with serpentinized harzburgite-dunite complex, small podiform chromitite bodies, and gabbroic intrusions. Serpentinite are exposed as narrow belts, which are separated by tectonic contacts from sedimentary rocks. The Cretaceous rocks combine BarremianAlbian conglomerate and Turonian limestone. The upper Eocene sequences consist of basal conglomerate overlain by flysch (siltstone, clay, sandstone, and limestone layers). The Pliocene sequences are widespread in the southern part of the area and consist of conglomerate, clayey sandstone with interbeds of calcareous clay, volcanosedimentary and pyroclastic rocks.

\section{GEOLOGY OF THE RŽANOVO DEPOSIT}

Several large dislocations crosscut the massif of serpentinized ultramafic rocks in the ore field. The Ržanovo Zone is a system of parallel thrust sheets composed of altered serpentinite, schist, and marble. The younger faults make up a radiate structure.

The ore lode at the deposit is traced for more than $4 \mathrm{~km}$ with a width of $1-40 \mathrm{~m}$. The lode is heterogeneous in structure and consists of several varieties of ores and rocks. Peridotite, gabbrodolerite, and serpentinites are the major ore-bearing rocks that have been subjected to weathering. Ultramafic rocks of the Ržanovo ore field correspond to Alpine-type ultrametamorphic rocks (Maksimovic, 1981) and do not differ from similar rocks elsewhere in Balkan Peninsula.

Albian-Cenomanian limestone, Cretaceous redeposited lateritic $\mathrm{Fe}-\mathrm{Ni}$ ore, presumably Cretaceous schists, serpentinite, gabbroic pegmatites and rodingite, as well as Tertiary volcanic rocks, participate in the geological structure of the deposit (Fig. 3).

Dunite and harzburgite are the most abundant Alpine ultramafic rocks in the Ržanovo ore field. They are strongly serpentinized and differ to a certain degree conditionally by microscopic examination. Harzburgite is characterized by enstatite crystals more than a centimeter in size visible to the naked eye. In addition, serpentinized harzburgite is commonly localized as homogeneous blocks distinguished from other rocks.

Serpentinite consists of flakes and fibers of serpentinite-group minerals, which almost completely replaces olivine and partly orthopyroxene in form of bastite pseudomorphs.

Serpentinized dunite occurs as large blocks. Serpentine replaces olivine as a network along irregular fractures (the first generation of serpentine) and as circular and radiate aggregates replacing particular portions of olivine grains. A small amount of powderlike magnetite appears as a product of serpentinization.

Gabbroic pegmatites and related rodingite in the $R \breve{z}$ anovo ore field are readily identified as small bodies, which crosscut serpentinite blocks. Unaltered gabbroic pegmatites are rarely observed. They consist of calcic plagioclase and clinopyroxene making up a coarse-grained aggregate. Clinopyroxene crystals occasionally reach $30 \mathrm{~cm}$ in size and are replaced with chlorite and prehnite, whereas in plagioclase, plagioclase prehnite appears infrequently and marks the onset of rodingite formation.

Rodingite alteration develops largely in marginal parts of the serpentinite massif as elongated blocks variable in thickness. Rodingite replaces gabbro and gabbroic pegmatite at the postmagmatic stage as a manifestation of calcic metasomatism. Contacts with adjacent serpentinite are always distinct. Rodingite consists of garnet (hydrogrossular), gibbsite, xenomorphic diopside, prehnite, and vesuvianite grains. Garnet is replaced with plagioclase; pyroxene is replaced with prehnite and chlorite.

Schists along other lithologic varieties play an important role in the geology of the Ržanovo ore field. 


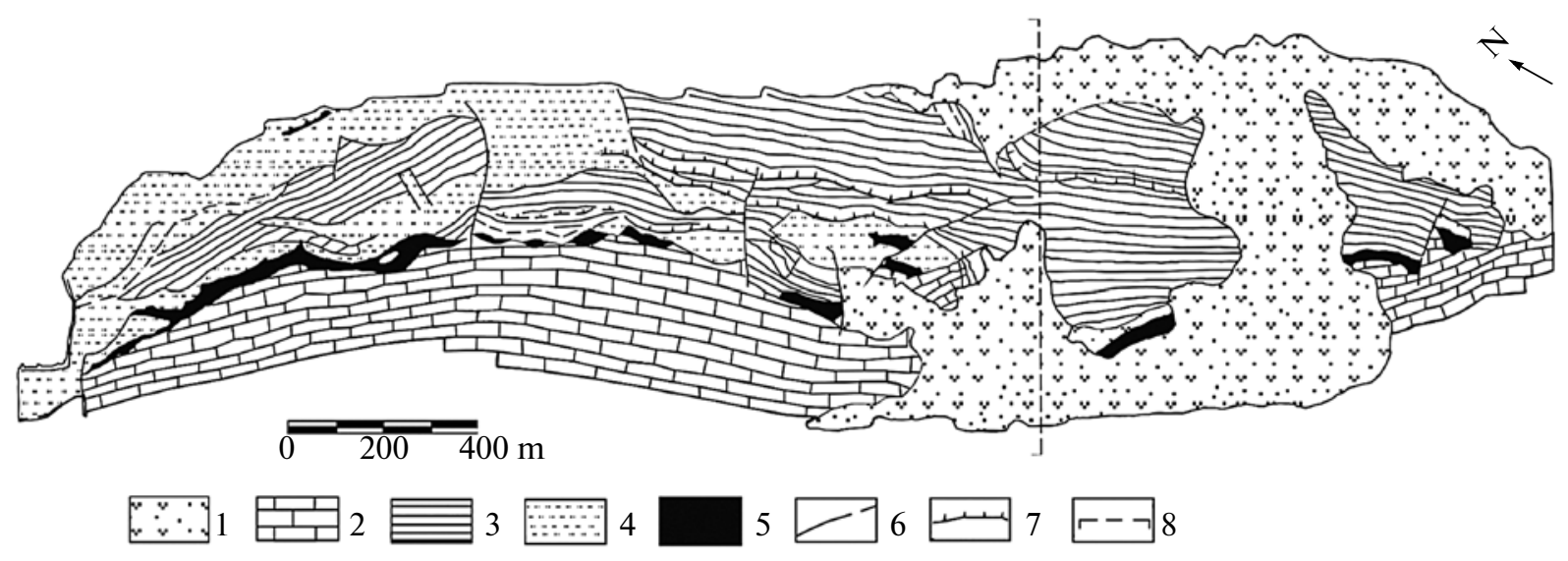

Fig. 3. Geological map of Ržanovo-Studena-Voda Fe-Ni deposit. (1) Tertiary volcanic and pyroclastic rocks; (2) Albian-Cenomanian limestones; (3) presumably Cretaceous schists; (4) serpentinite, gabbroic pegmatite, and rodingite; (5) lateritic $\mathrm{Fe}-\mathrm{Ni}$ ore; (6) fault; (7) thrust fault; (8) section line, see Fig. 4.

Schists are composed of quartz, sericite and illite, chlorite, albite, and talc. These minerals were identified by XRD. The mineral composition shows that clay was transformed into schists under conditions of greenschist facies.

Metasandstone occurs locally as lenses in the schist sequence; the rock contains quartz and less frequent microcline or plagioclase clastic grains; tourmaline is a rare mineral. The matrix is completely recrystallized and mainly composed of quartz with a small amount of calcite. This indicates that the protolith was arkosic with an initial quartz or clayey-cherty matrix.

Limestones occur in the upper part of the AlbianCenomanian ore-bearing sequence and are occasionally overturned. The rock is only slightly metamorphosed.

\section{OREBODY MORPHOLOGY}

The morphology of orebody at the Ržanovo deposit directly depends on formation conditions of $\mathrm{Fe}-\mathrm{Ni}$ ore layer as a result of scouring and redeposition of lateritic aposerpentinite weathering mantle during Jurassic and Early Cretaceous. The $\mathrm{Fe}-\mathrm{Ni}$ deposit is localized at the contact between Jurassic serpentinite and schist in the footwall and Cretaceous limestone in the hanging wall.

The orebody dips nearly vertical and is overturned with Cretaceous sedimentary rocks in the footwall and the Jurassic serpentinite in the hanging wall of the orebody (Fig. 4). The inversion was as a result of tectonic movement at the end of Jurassic.

As can be seen from geological section, the orebody is confined to the base of Cenomanian-Turonian limestones. At the surface it is traced for $\sim 4 \mathrm{~km}$ with an average thickness of $30-50 \mathrm{~m}$. The orebody is partly overlain by the thrust fault and by Neogene andesite in its southern part. It should be noted that in the depth interval of 955-470 m.a.s.l. (approximately $500 \mathrm{~m}$ by vertical), the orebody lies without indications of pinch-out and is continuous despite intense dislocations in this region. The orebody plunges to eastnortheast, bends with depth toward the southwest, and looks like a slightly curved sheet (Fig. 5).

One can seen in geological sections that although the orebody retains vertical attitude, its thickness and morphology underwent significant changes with depth (Fig. 5). Section 17-17' shows that the orebody bends and divides into two thinner offsets (Fig. 5a). In the next section $18-18^{\prime}$, it is a thickened lens between levels 750 and 640 m.a.s.l. and abruptly decreases in thickness below 640 m.a.s.l. (Fig. 5b). In the next sections, we see quite different patterns. In section 21-21' (Fig. 5c), the orebody continuously extends from the surface to a level of 520 m.a.s.l., insignificantly increasing in thickness, while in section 25-25' (Fig. 5d), it is thin at the surface and gradually increases in thickness with depth. These sections show that the orebody is not interrupted with depth. Further exploration must corroborate this conclusion.

The aforementioned morphological features show that the orebody at the Ržanovo deposit consists of several segments with specific lithologic, mineralogical, and geochemical characteristics.

\section{MINERAL TYPES OF ORE}

Like the preceding investigations, our study has shown that the orebody at the Ržanovo deposit is composed of the following types of ores and mineralized rocks: massive and fissile magnetite ores; oolitic, fissile, and massive hematite ores; riebeckite, stilpnomelane and dolomite-talc schists; and serpentinite. The overview of the most important ore types is given 


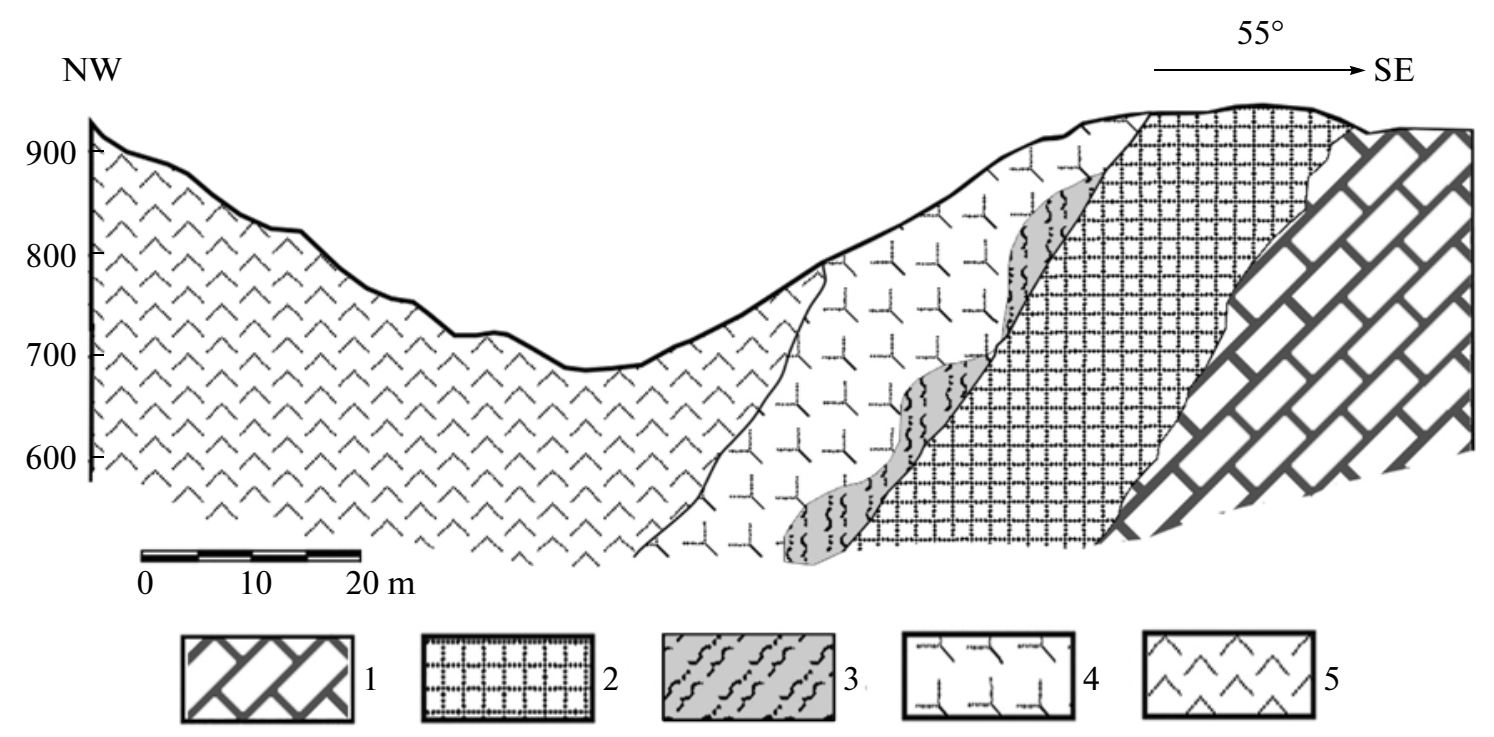

Fig. 4. Geological section across Ržanovo deposit, modified after Ivanov (1962). (1) Cretaceous limestone; (2) lateritic Fe-Ni ore; (3) nontronite clay; (4) nontronized serpentinite; (5) serpentinite.

below. The mineralogical composition of ore is given in Table 1 and chemical composition in Table 2.

Massive magnetite ore occur in the upper part of ore layer. Magnetite is the predominant mineral. Hematite, clinochlore, talc, sepiolite, dolomite, and amphibole are also widespread (Table 1). The ore of this type contains chemical elements inherited from ultramafic rocks, in particular, $\mathrm{Ni}, \mathrm{Co}$, and $\mathrm{Cr}$. The $\mathrm{Ni}$ content in ore varies from 0.69 to $1.17 \%$ (Table 2).

Fissile magnetite ore is distinguished by a rather high Ni content (1.10-1.28\%) (Table 2) and by a relatively high $\mathrm{Na}$ content $(0.55-0.84 \%)$. The elevated $\mathrm{Na}$ content reflects the enrichment of ore in riebeckite. In addition to magnetite, the ore contains hematite, talc, clinochlore, amphibole, and dolomite (Table 1).

Fissile hematite ore, which is the most abundant at the Ržanovo deposit (Fig. 6a), contains $0.70-1.27 \%$ $\mathrm{Ni}$ and $0.50-0.82 \% \mathrm{Na}$. The Fe content is a rather high; the Mg content varies from 12 to $17 \%$ (Table 2). The ore is characterized by high concentrations of chemical elements inherent to ultramafic rocks, as well as high concentrations of $\mathrm{Zr}$ (Boev and Jankovic, 1996). Magnetite, hematite, talc, clinochlore, and amphibole are the most abundant; pyrite is sporadic (Table 1).

Oolitic hematite ore is also abundant at the Ržanovo deposit. It has distinct oolitic-pisolitic texture (Fig. 6b) and contains $0.91-1.25 \% \mathrm{Ni}$ (Table 2). This lithologic type of ore is enriched in Fe contained in hematite and chemical elements related to ultramafic rocks (Boev and Jankovic, 1996). The $\mathrm{Zr}$ content (275 ppm) is probably related to schists as a source. The ore contains magnetite, hematite, talc, clinochlore, amphibole, and a small amount of sepiolite.
Massive hematite ore is also widespread at the Ržanovo deposit. It is characterized by massive texture, high hardness, and relatively high $\mathrm{Ni}$ grade $(0.93-1.49 \%)$. The high $\mathrm{Na}$ content $(0.53-1.38 \%)$ indicates abundant amphibole. High $\mathrm{Ni}, \mathrm{Cr}$, and $\mathrm{Co}$ contents are also noted (Boev and Jankovic, 1996). Magnetite, clinochlore, talc, and amphibole occur in the ore in addition to hematite (Table 2).

Riebeckite and stilpnomelane schists are not abundant at the Ržanovo deposit and are readily identified by color and structure: riebeckite schist is blue, whereas stilpnomelane schist is yellowish. These are typically metamorphic rocks. Riebeckite schist is composed largely of riebeckite, talc, lizardite, phlogopite, digenite, and pyrrhotite, whereas stilpnomelane schist, of stilpnomelane, talc, maghemite, lizardite, dolomite, quartz, and pyrite (Table 1). The Ni contents in riebekite and stilpnomelane schists are $>2 \%$ and $\sim 1.1 \%$, respectively (Table 2 ).

Dolomite-talc schist is a relatively rare lithologic type of mineralization at the Ržnovo deposits and is distinguished by reddish color because of a high $\mathrm{Fe}$ content. This type of ore contains $0.80-1.06 \% \mathrm{Ni}$, i.e., less than other ore types (Table 2). The schist is enriched in $\mathrm{Ca}, \mathrm{Na}$, and $\mathrm{Mg}$. The rock contains talc, dolomite, hematite, magnetite, amphibole, lizardite, and clinochlore (Table 1).

Talc schist occurs at the Ržanovo deposit along fault zones and tectonic slickensides (Fig. 7). Ore of this type is greenish in color and contains small magnetite crystals. As is shown in Table 1, the ore is enriched in $\mathrm{MgO}$ and $\mathrm{SiO}_{2}$, whereas the Fe content is relatively low as compared with other ore types; the $\mathrm{Ni}$ content is not high $(0.34-0.75 \%)$. Several generations of Ni-bearing talc schists probably exist. This type of 
(a)

Geological section along line 17-17' (b)

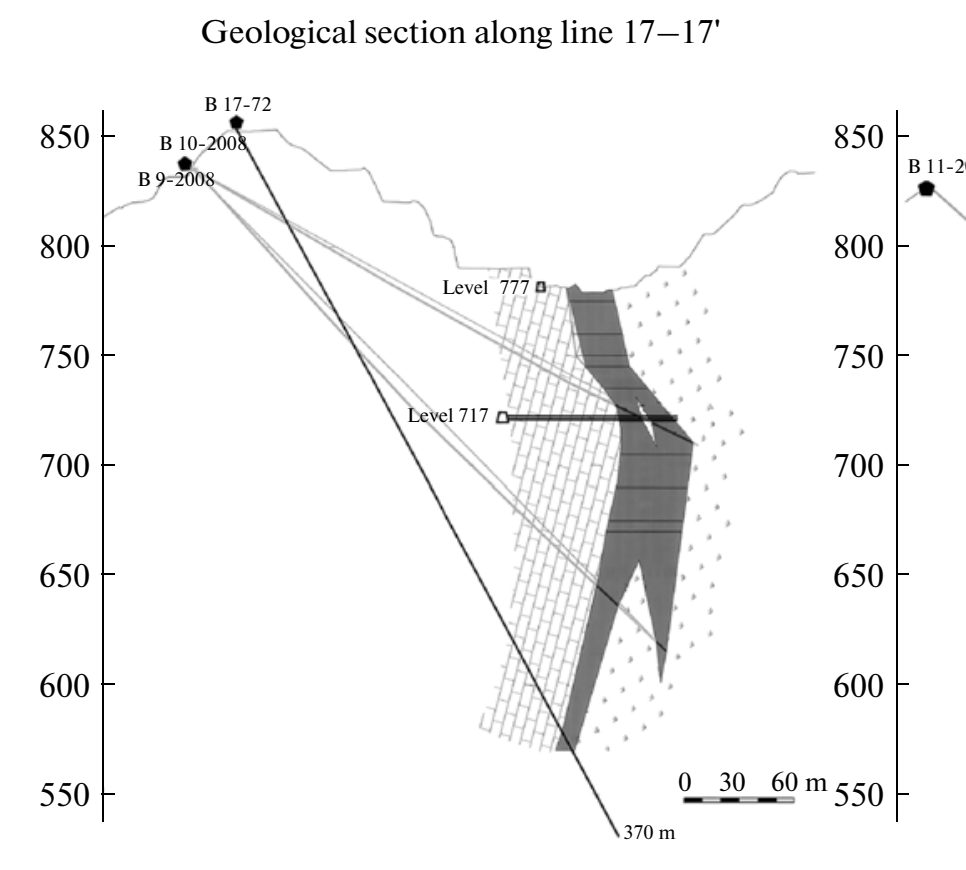

Geological section along line 18-18' B 17-46(48) (c)

Geological section along line 21-21

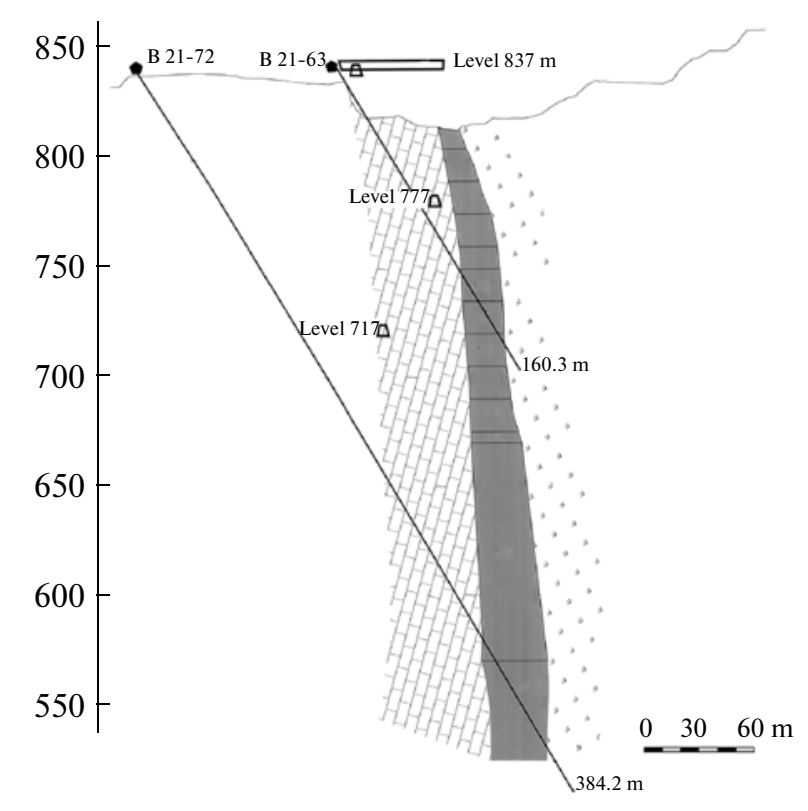

\section{Geological section along line 25-25'}

along line 25-25'

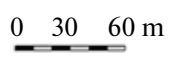

$0 \quad 30 \quad 60 \mathrm{~m}$

900
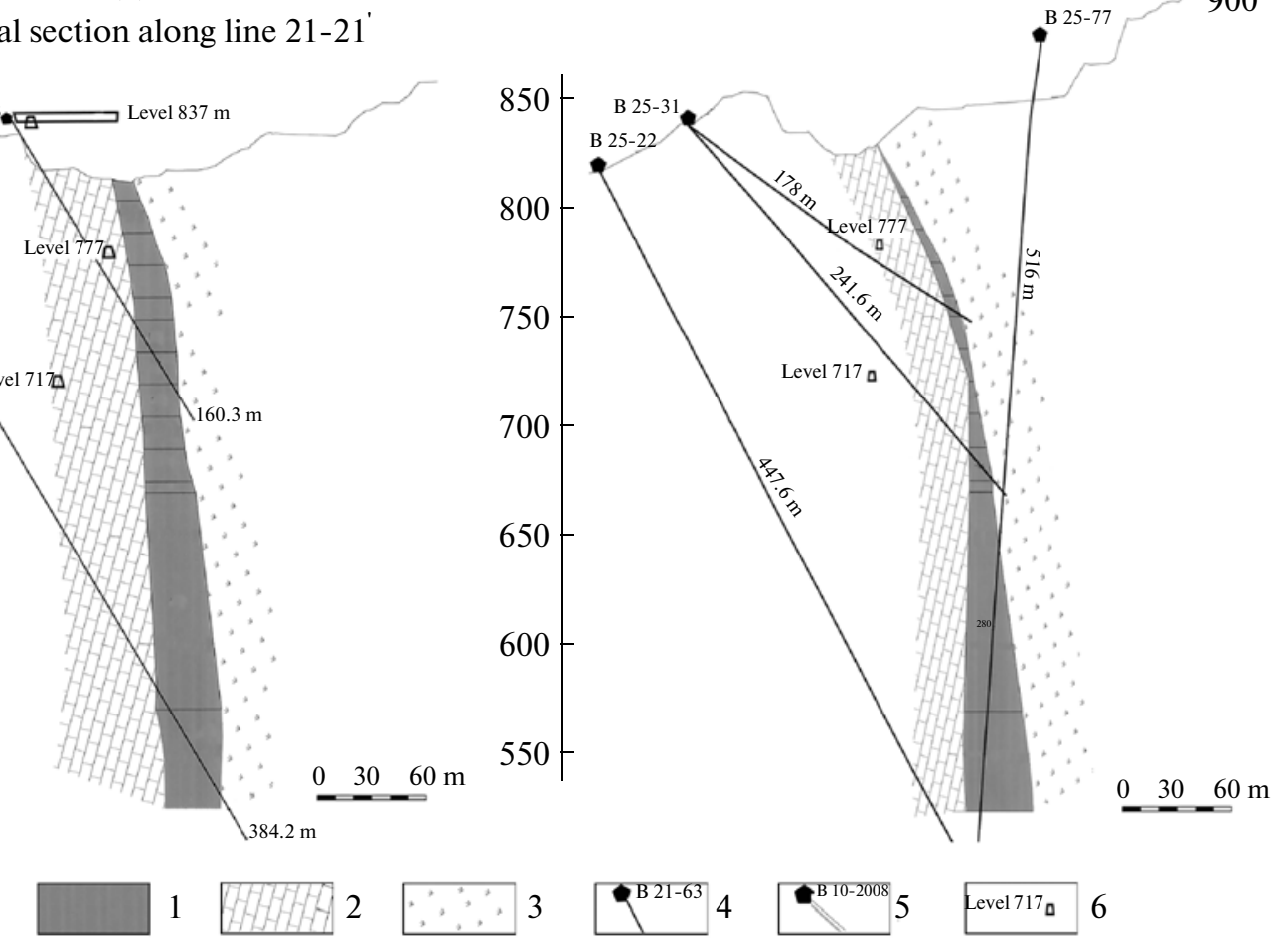

Fig. 5. Geological sections across Ržanovo deposit along exploration lines: (a) 17-17', (b) 18-18', (c) 21-21', (d) 25-25', after data of geological survey of mine, 2011. (1) Orebody; (2) limestone; (3) serpentinite; $(4,5)$ drill holes: (4) old and (5) new; (6) exploration adit.

ore consists largely of talc, clinochlore, magnetite, hematite, and lizardite (Table 2).

Serpentinite type of ore is typical of the Ržanovo deposit, where it occurs as lenses within contour of economic orebody. This type of ore is depleted in $\mathrm{Fe}$ and $\mathrm{Ni}$ but enriched in $\mathrm{MgO}$ and $\mathrm{SiO}_{2}$ (Table 1). The ore consists of lizardite, hematite, dolomite, talc, and magnesite (Table 2). 

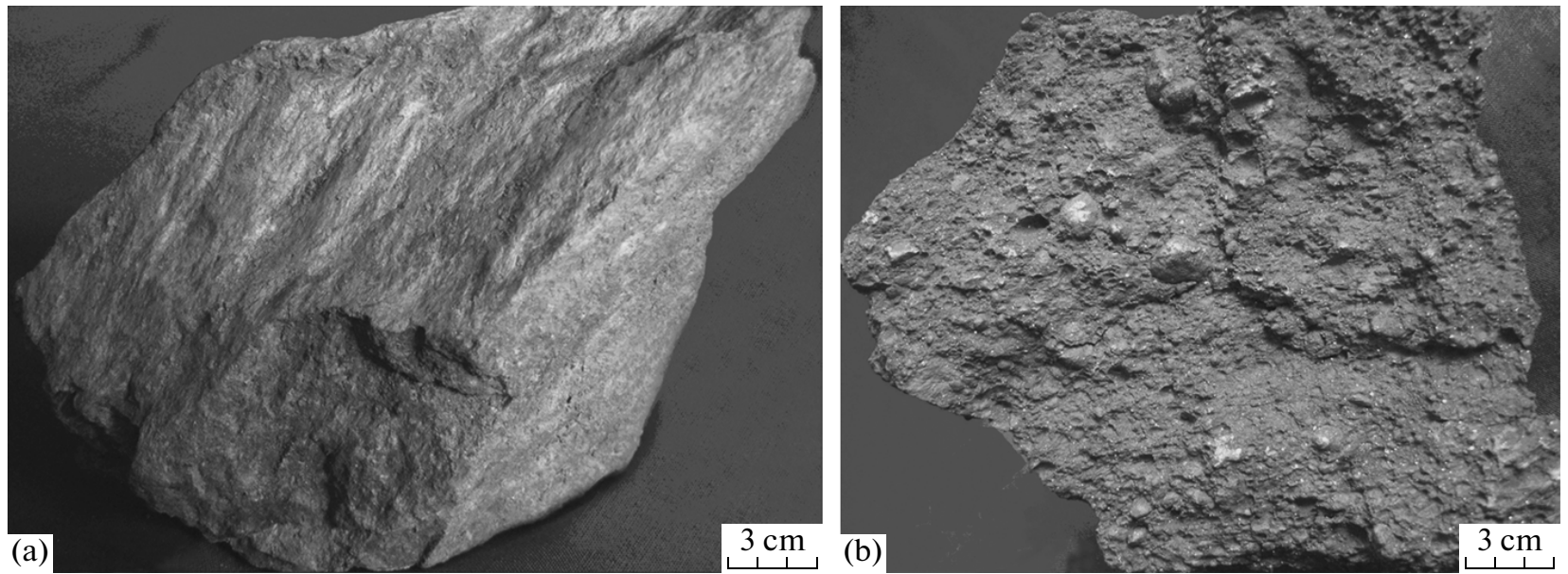

Fig. 6. Main ore types at Ržanovo deposit: (a) fissile hematite ore and (b) oolitic hematite ore.

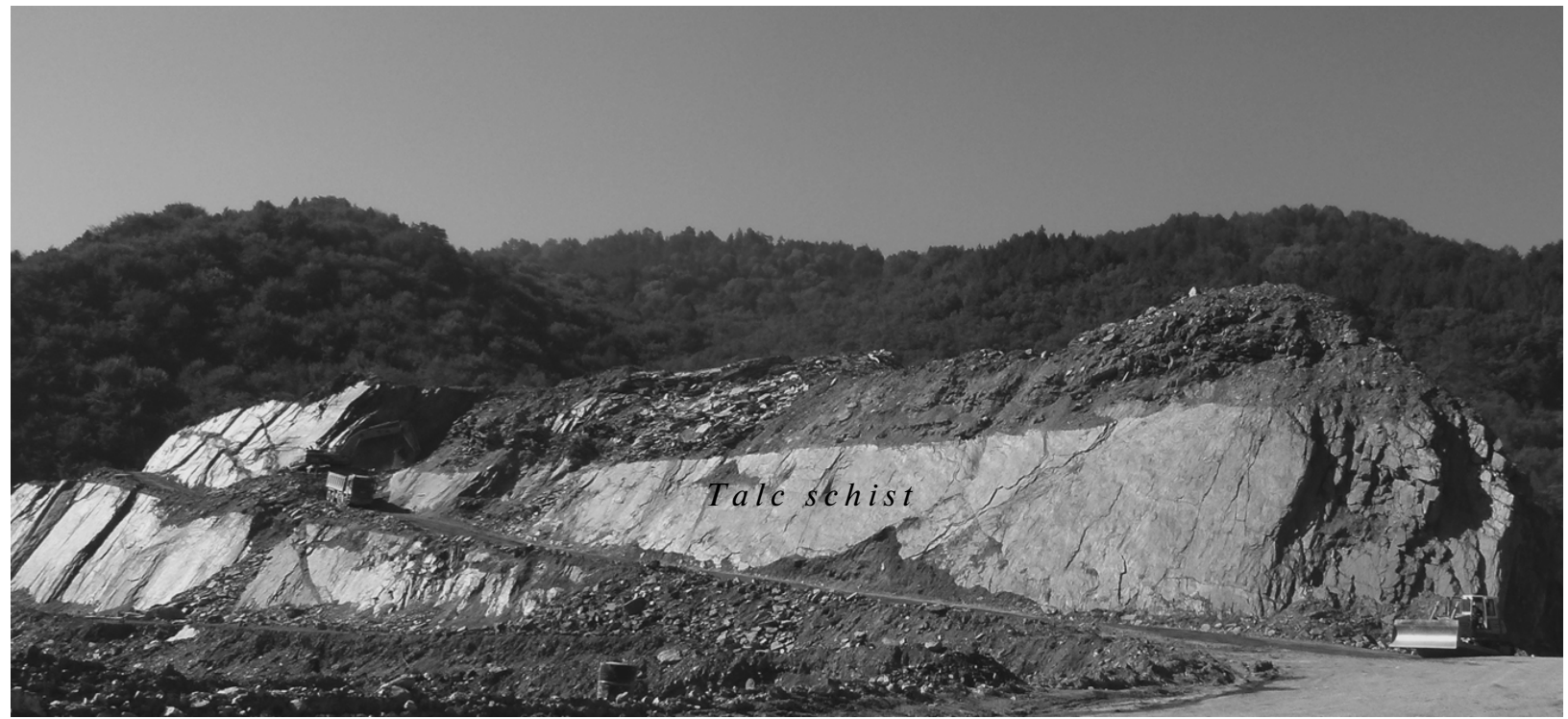

Fig. 7. Talc schist at wall of Ržanovo open pit. Photo by A.V. Volkov (2012).

\section{MINERALOGY AND GEOCHEMISTRY OF ORE}

The ore at the Ržanovo deposit is a complex multiphase mineral system with variable mineral assemblages and variable Ni contents in the minerals pertaining to different ore types. These variations are primarily related to superposition of several processes or more specifically to variations of physicochemical and thermodynamic conditions of accumulation, migration, precipitation of nickel and its redistribution during dynamometamorphism. The determination of the $\mathrm{Ni}$ content in major mineral phases pertaining to certain chronological stages is not a readily solvable problem for such a multiphase system due to the small size of particular mineral grains, which can be studied only using a microprobe. With our significant experience in studying such types of ore, we present new data on the chemical composition of the mineral phases and $\mathrm{Ni}$ content therein.

Amphibole in ore from the Ržanovo deposit is distributed nonuniformly and occurs as oblong (up to acicular) and prismatic crystals accumulated into asbestos-like aggregates blue in color and occasionally with a yellow hue. According to analytical results, amphibole belongs to magnesian riebeckite; $\mathrm{SiO}_{2}$, $\mathrm{FeO}$, and $\mathrm{MgO}$ dominate in its composition (Table 3 ). Amphibole is one of the main Ni-bearing minerals in the ore $(1.61 \mathrm{wt} \% \mathrm{NiO})$.

The content of chlorite in ore is $\sim 11 \%$. The mineral occurs as phyllic aggregates with a characteristic yellowish green color. According to microprobe results, chlorite corresponds to clinochlore in composition and contains up to $2.87 \% \mathrm{NiO}$ (Table 3 ). 


\begin{tabular}{|c|c|c|c|c|c|c|c|c|c|c|c|c|c|c|c|c|c|c|}
\hline 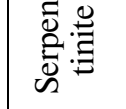 & $\stackrel{0}{>}$ & $=$ & $\bar{\sim}$ & & లి & & & & 0 & & & & లి & & & & $\stackrel{\infty}{\curvearrowleft}$ & $\begin{array}{l}\frac{7}{2} \\
0 \\
\frac{0}{2}\end{array}$ \\
\hline 栉 & $\stackrel{\infty}{\Xi}$ & $\infty$ & & & ळे & & & & & & & & & & & & à & 营 \\
\hline$\frac{0}{\pi}$ & $\frac{0}{5}$ & 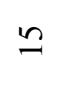 & 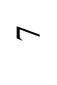 & & ț & & & & & & & $a$ & & & & & 2 & $\stackrel{\bar{N}}{3}$ \\
\hline$\frac{0}{\tilde{J}}$ & $\stackrel{ \pm}{\Xi}$ & in & F & 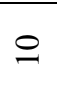 & $\hat{m}$ & & & $n$ & & & & & & & & & જे & 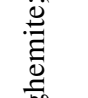 \\
\hline 总泀 & $\stackrel{\Re}{\S}$ & $\infty$ & స & 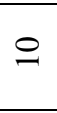 & $\stackrel{\infty}{n}$ & & & $n$ & & & & & & & & & $\hat{a}$ & \\
\hline 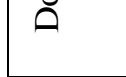 & $\bar{\delta}$ & & $\infty$ & & $\stackrel{\Delta}{\sim}$ & & $\stackrel{ \pm}{\sim}$ & $\stackrel{\sim}{\sim}$ & & & & 0 & & & & & $\propto$ & \\
\hline 官 & 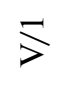 & & & & సิ & & & $m$ & $n$ & F & $r$ & 은 & & & $=$ & & $\approx$ & \\
\hline 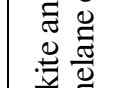 & $\Xi$ & & & సิ & $\cong$ & & & & & Әे & $\ddot{m}$ & & & & & & $\propto$ & \\
\hline 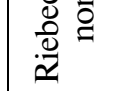 & $\stackrel{\infty}{=}$ & & & & 0 & & $n$ & n & & & & 6 & $\sim$ & 으 & & 6 & $\infty$ & \\
\hline ๑ రั & $\stackrel{\Xi}{\Xi}$ & 6 & 8 & $a$ & $\cong$ & & $=$ & & & & & & & & & & જे & \\
\hline 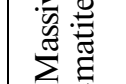 & $\stackrel{ \pm}{\Xi}$ & $\infty$ & nิ & $\simeq$ & $=$ & & $a$ & & & & & & & & & & ลे & \\
\hline$\Xi$ & $\stackrel{\infty}{=}$ & $a$ & $\bar{n}$ & $\infty$ & 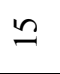 & & 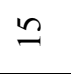 & & & & & & & & & & $\stackrel{\infty}{a}$ & \\
\hline & $\stackrel{\curvearrowright}{\Xi}$ & $\widetilde{N}$ & $\stackrel{\infty}{\sim}$ & \pm & $\stackrel{\infty}{\sim}$ & & & & 6 & & & & & & & & $\stackrel{\infty}{\curvearrowleft}$ & \\
\hline $\begin{array}{l}\mathscr{0} \\
0.0\end{array}$ & $\lesssim$ & 6 & 8 & $\cong$ & 으 & & 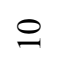 & & & & & & & & & & $\stackrel{\infty}{\sigma}$ & \\
\hline$\tilde{n}^{\infty}$ & $\stackrel{\varrho}{\Omega}$ & 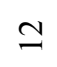 & $i$ & $\cong$ & $\cong$ & & & & & & & & & & & & $\stackrel{\infty}{\alpha}$ & \\
\hline$\stackrel{\stackrel{\mathscr{E}}{\overparen{\Xi}}}{\Xi}$ & $\stackrel{\circ}{\Omega}$ & $\nabla$ & $n$ & $=$ & $=$ & & $\beth$ & & & & & & & & & & $\stackrel{\circ}{\circ}$ & $\stackrel{0}{0}$ \\
\hline$\frac{\mathscr{0}}{0}$ & $\stackrel{2}{2}$ & in & $?$ & $\simeq$ & $\simeq$ & & & & & & & & & & & & ๙ & \\
\hline & $\stackrel{\mathrm{N}}{\mathrm{S}}$ & $=$ & ஜ & 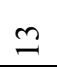 & 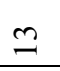 & in & & & & & & & & & & & $\stackrel{\infty}{a}$ & \\
\hline 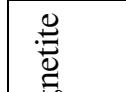 & 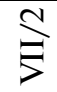 & ఉా & $\varrho$ & $a$ & $\mathcal{F}$ & $m$ & & & & & & & & & & & $\propto$ & \\
\hline 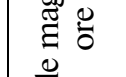 & $\Sigma$ & $\stackrel{n}{\sim}$ & $\stackrel{\infty}{-}$ & ㄱ. & $\underline{-}$ & & $n$ & \pm & & & & & & & & & $\stackrel{\infty}{a}$ & \\
\hline & $\lesssim$ & $\overline{6}$ & & $\approx$ & $\bumpeq$ & & & & & & & & & & & & $\stackrel{\infty}{\Omega}$ & \\
\hline 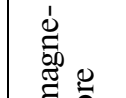 & $\lesssim$ & $\tilde{\text { ก }}$ & $\Xi$ & $\Xi$ & q & $n$ & - & $m$ & & & & & & & & & ฉ & 2 \\
\hline 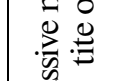 & $\frac{1}{2}$ & $\infty$ & - & $a$ & $a$ & $a$ & $\sim$ & - & & & & & & & & & ฉे & \\
\hline & $\Sigma$ & m & $r$ & $n$ & $\stackrel{\text { I }}{\text { f }}$ & & & & & & & & & & & & $\stackrel{\circ}{a}$ & \\
\hline \multicolumn{2}{|c|}{ : } & $\sum^{ \pm}$ & $\Xi$ & $\overline{\bar{U}}$ & 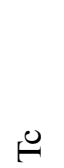 & ڤ & 突 & ๑̊ & 2 & $\overline{\tilde{n}}$ & $\sum^{\frac{5}{60}}$ & $\stackrel{N}{3}$ & $\frac{0}{\frac{1}{2}}$ & 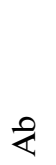 & 0 & $\stackrel{.00}{0}$ & 芫 & 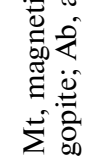 \\
\hline
\end{tabular}




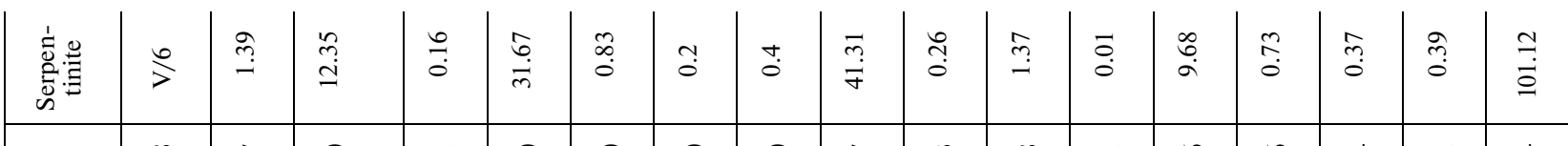

\begin{tabular}{|c|c|c|c|c|c|c|c|c|c|c|c|c|c|c|c|c|}
\hline$\stackrel{\infty}{\Xi}$ & $\hat{\tilde{o}}$ & 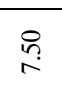 & $\overline{0}$ & 8 & R. & $\stackrel{0}{0}$ & ถి & 它 & ?ֶ: & 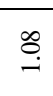 & $\bar{o}_{0}$ & 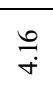 & $\stackrel{\circ}{\circ}$ & 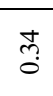 & $\overline{\mathrm{s}}$ & th \\
\hline$\stackrel{0}{5}$ & $\stackrel{\leftrightarrow}{*}$ & $\stackrel{\Xi}{\exists}$ & ్ֻరి & $\begin{array}{l}\text { ț } \\
\text { d. }\end{array}$ & ถิ & $\stackrel{\infty}{0}$ & ?ִ & 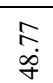 & đั & $\stackrel{\leftrightarrow}{\circ}$ & $\vec{o}_{0}$ & $\begin{array}{l}\overrightarrow{6} \\
i\end{array}$ & ల్ల & $\stackrel{n}{n}$ & $\begin{array}{l}0 \\
0 \\
0\end{array}$ & $\ddot{8}$ \\
\hline
\end{tabular}

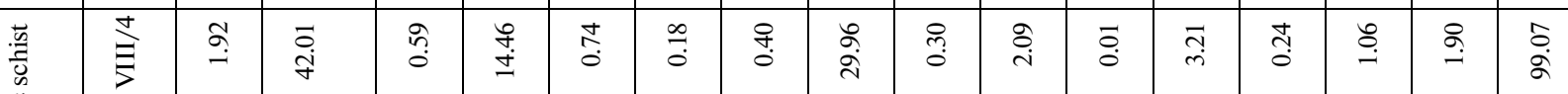

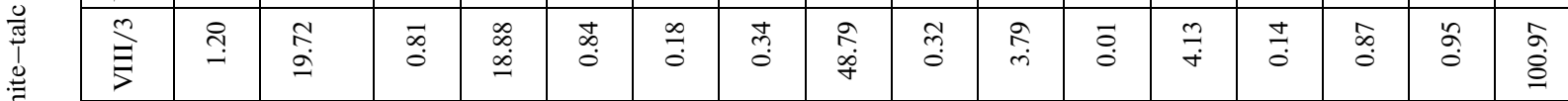

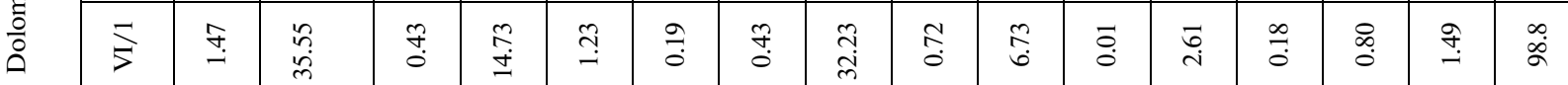

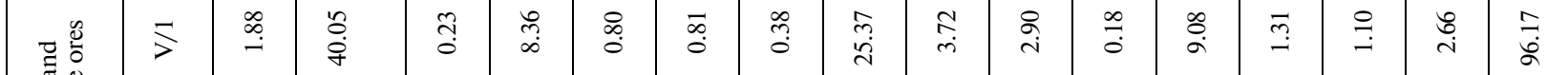

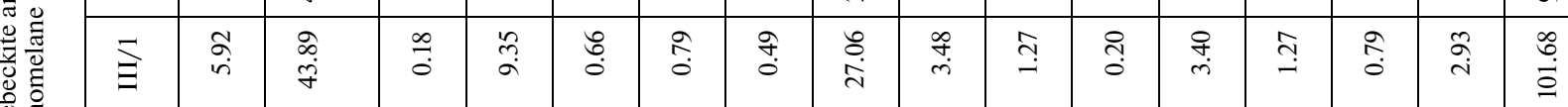

so

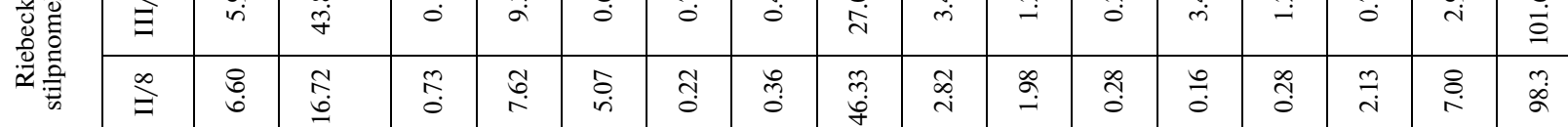

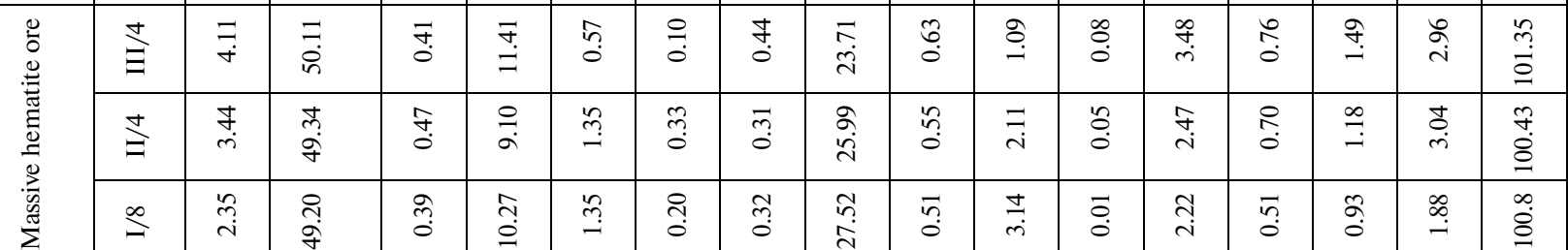

西

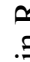

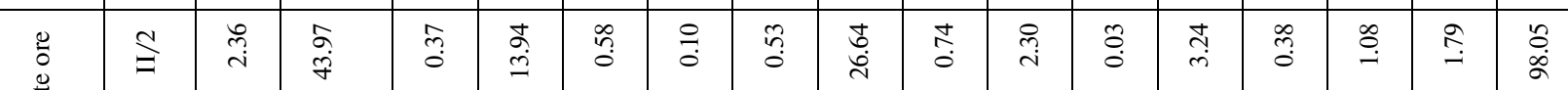

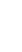

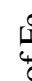

虫

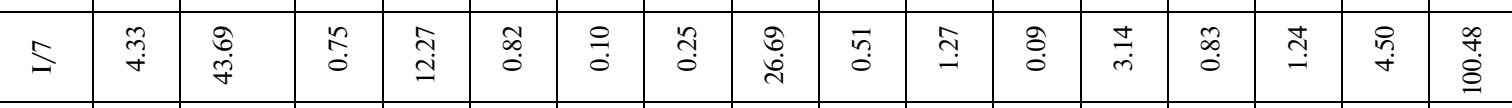

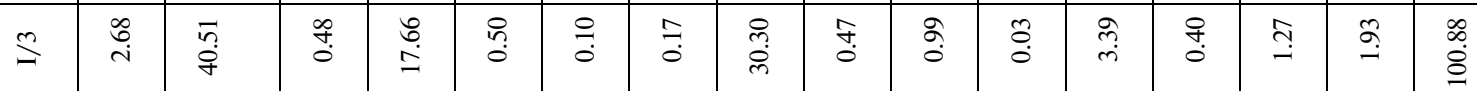

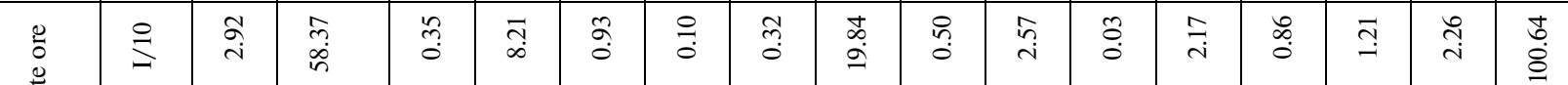

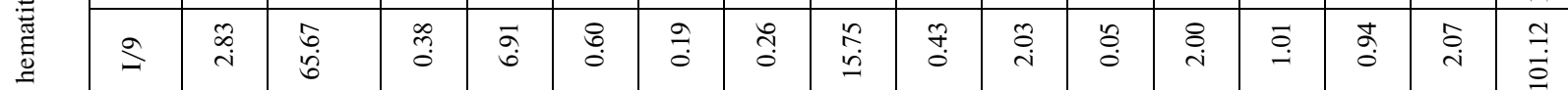

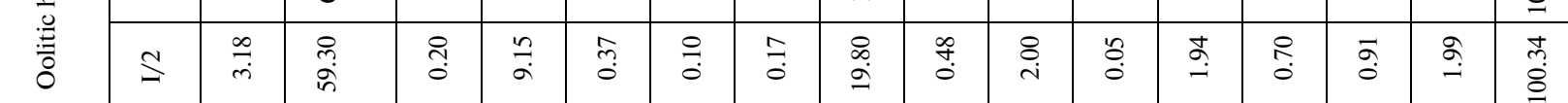

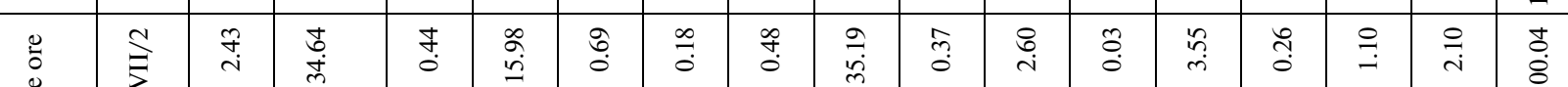

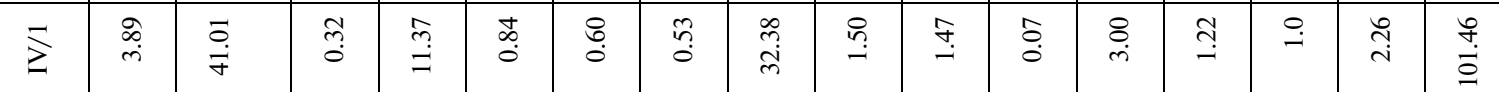

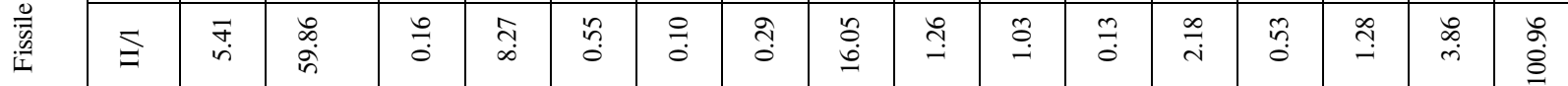

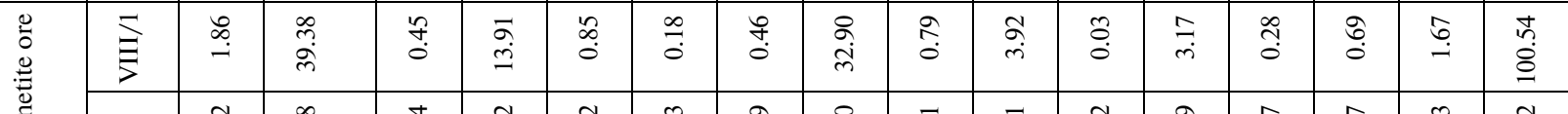

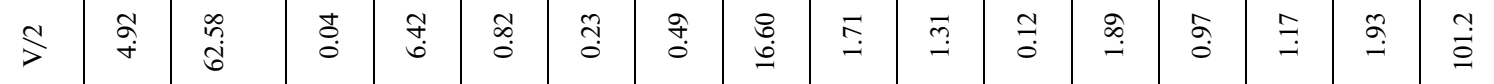

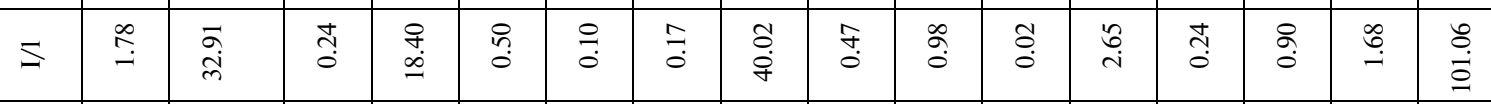

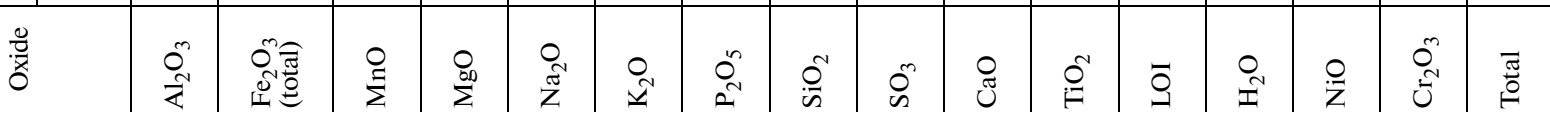



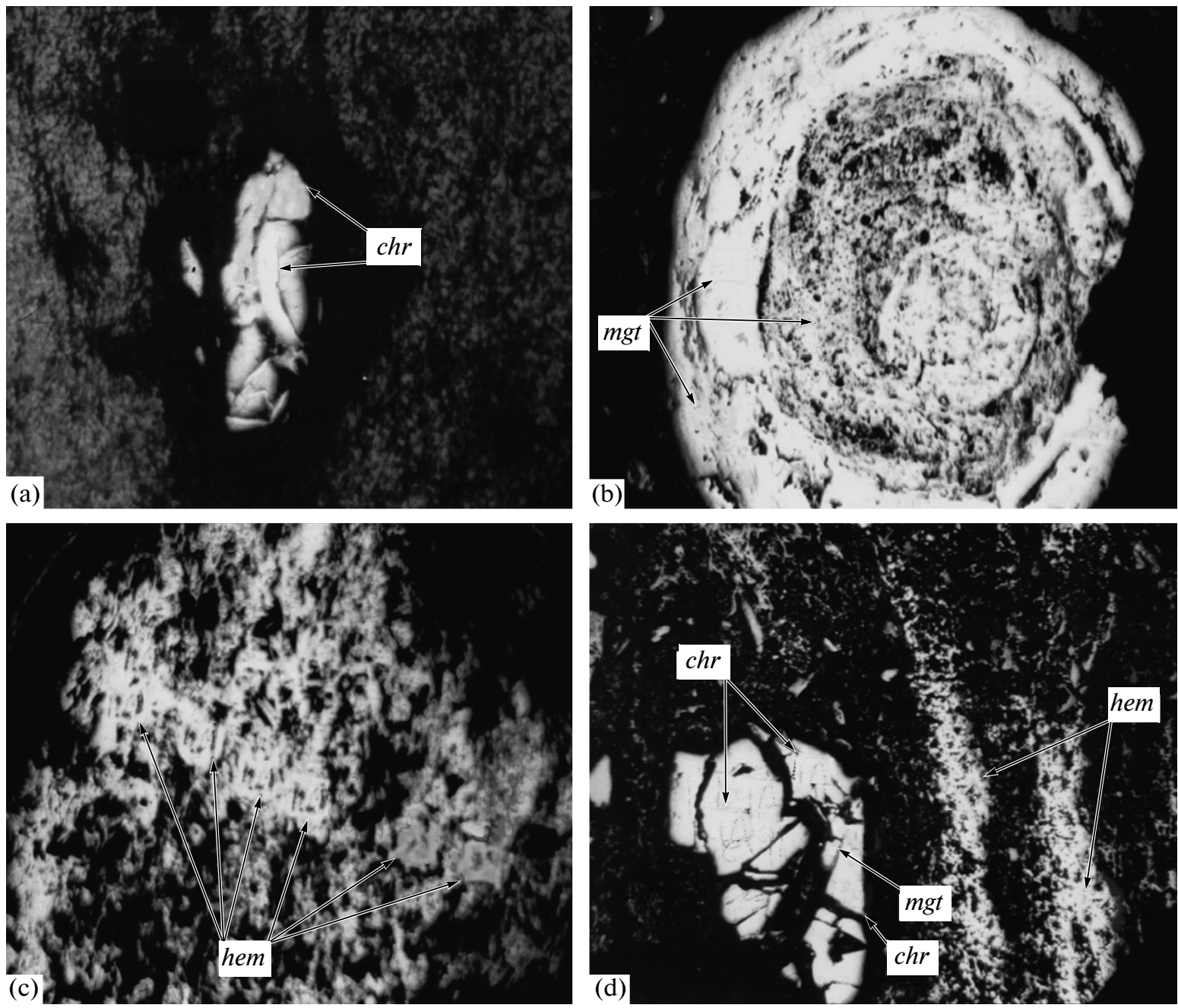

Fig. 8. Photomicrographs of major mineral aggregates in the Ržanovo Fe-Ni deposit: (a) chromite, (b) magnetite, (c) hematite, (d) chromite-magnetite-hematite aggregate. Magn. 200 (reflected light).

Fine-grained talc aggregates are scattered throughout the ore matrix and together with hematite make up the groundmass of the ore. Talc contains $1.93 \% \mathrm{NiO}$ (Table 3).

The stilpnomelane content in ore of the Ržanovo deposit commonly varies from 0.5 to $0.7 \%$, markedly increasing in locally developed stilpnomelane schists (Table 3). This mineral from the group of brittle micas occurs as phyllic and fibrous aggregates visually resembling biotite. Stilpnomelane contains up to $1.22 \% \mathrm{NiO}$ (Table 3 ).

Calcite is distributed sporadically in ore of the Ržanovo deposit $(<0.3 \%$, Table 1$)$; local sites are enriched in this mineral. Calcite crystals and grains vary in color from white to yellow. The transparent twinned tabular and rhombohedral crystals are characterized by distinct birefringence. The results of microprobe analyses of calcite are given in Table 3.

Hematite, magnetite, and chromite. The microprobe analyses of these minerals are given in Table 4 . The Ni contents are as follows: magnetite $(0.00-2.94 \% \mathrm{NiO}$; $0.81 \%$, on average); hematite $(0.00-0.59 \% \mathrm{NiO}$; $0.14 \%$, on average); chromite $(0.00-0.46 \% \mathrm{NiO}$; $0.05 \%$, on average).

The samples of ore with characteristic oolitic structure were specially studied (Figs. 8, 9). The relationships between major ore minerals, primarily between chromite and magnetite, as well as magnetite and hematite, are shown in Fig. 8. Euhedral and subhedral chrome minerals often occur as cores within magnetite grains with the formation of oolitic texture (Fig. 9a, 9b). The compositions of the studied minerals are rather stable with some variations of $\mathrm{Fe}$ in magnetite (66$68 \%$ ) and chromite (Table 4). The most stable composition is typical of hematite, where the $\mathrm{Fe}$ and $\mathrm{O}$ contents are close to stoichiometric values, whereas the contents of $\mathrm{Mg}$ and $\mathrm{Al}$ admixtures are close to the upper limit; the Cr content reaches $1.28 \%$ (Table 4). It should be emphasized (Fig. 9) that in some samples with oolitic structure magnetite, hematite, and 
Fig. 3. Chemical composition of major Ni-bearing minerals from ore in Ržanovo deposit, results of microprobe analysis

\begin{tabular}{|c|c|c|c|c|c|c|c|c|c|c|c|c|c|}
\hline \multirow{2}{*}{ Mineral } & \multicolumn{12}{|c|}{ Chemical composition, wt $\%$} & \multirow{2}{*}{ Total } \\
\hline & $\mathrm{SiO}_{2}$ & $\mathrm{TiO}_{2}$ & $\mathrm{Cr}_{2} \mathrm{O}_{3}$ & $\mathrm{Al}_{2} \mathrm{O}_{3}$ & $\mathrm{FeO}$ & $\mathrm{MnO}$ & $\mathrm{MgO}$ & $\mathrm{NiO}$ & $\mathrm{CaO}$ & $\mathrm{Na}_{2} \mathrm{O}$ & $\mathrm{K}_{2} \mathrm{O}$ & $\mathrm{H}_{2} \mathrm{O}$ & \\
\hline $\begin{array}{l}\text { Riebeck- } \\
\text { ite }\end{array}$ & 55.99 & 0.01 & 0.05 & 0.8 & 20.6 & 0.62 & 10.67 & 1.59 & 1.09 & 5.95 & 0.04 & & 97.41 \\
\hline$"$ & 52.39 & 0.02 & 2.51 & 1.02 & 21.9 & 0.76 & 9.23 & 2.03 & 1.35 & 6.11 & 0.05 & & 97.37 \\
\hline$"$ & 54.72 & 0 & 2.63 & 1.35 & 18.13 & 0.65 & 9.83 & 2.22 & 2.08 & 5.72 & 0.02 & & 97.35 \\
\hline$"$ & 54.51 & 0 & 1.99 & 1.45 & 20.78 & 0.59 & 9.86 & 1.08 & 1.14 & 6.41 & 0.02 & & 97.83 \\
\hline$"$ & 55.09 & 0.01 & 1.54 & 2.22 & 17.9 & 0.58 & 9.86 & 2.56 & 2.2 & 5.65 & 0.05 & & 97.66 \\
\hline$"$ & 56.16 & 0 & 0.03 & 1.0 & 21.61 & 0.78 & 9.93 & 1.09 & 1.04 & 6.10 & 0.04 & & 97.78 \\
\hline " & 55.79 & 0 & 0 & 1.15 & 21.38 & 0.7 & 9.04 & 1.98 & 1.03 & 6.47 & 0.05 & & 97.59 \\
\hline$"$ & 56.67 & 0 & 0.04 & 1 & 21.25 & 0.78 & 9.54 & 1.35 & 1.06 & 6.19 & 0.06 & & 97.94 \\
\hline$"$ & 56.89 & 0 & 0.06 & 0.64 & 20.31 & 0.56 & 10.68 & 1.78 & 1.01 & 6.02 & 0.04 & & 97.99 \\
\hline$"$ & 56.42 & 0 & 0 & 0.81 & 20.08 & 0.62 & 11.20 & 1.9 & 1.03 & 5.92 & 0.04 & & 97.61 \\
\hline$"$ & 55.66 & 0.02 & 0.43 & 1.08 & 19.37 & 0.63 & 9.92 & 2.50 & 2.32 & 5.94 & 0.05 & & 97.92 \\
\hline$"$ & 54.69 & 0.03 & 0 & 0.94 & 25.84 & 0.29 & 7.78 & 0.63 & 1.43 & 5.95 & 0.05 & & 97.63 \\
\hline$"$ & 55.11 & 0.01 & 0 & 0.86 & 23.1 & 0.3 & 9.44 & 0.38 & 2.23 & 5.77 & 0.02 & & 97.22 \\
\hline$"$ & 55.4 & 0.01 & 0.03 & 0.92 & 23.56 & 0.22 & 10.05 & 0.23 & 1.2 & 6.27 & 0.02 & & 97.91 \\
\hline$"$ & 53.49 & 0.02 & 0.28 & 1.29 & 26.2 & 0.24 & 8.13 & 0.71 & 0.68 & 6.45 & 0.05 & & 97.54 \\
\hline Chlorite & 33.07 & 0.01 & 14.09 & 0.51 & 7.74 & 0.61 & 30.07 & 2.09 & 0.04 & 0.02 & 0.01 & 11.67 & 99.93 \\
\hline$"$ & 32.79 & 0.03 & 15.09 & 0.31 & 6.06 & 0.33 & 31.44 & 0.88 & 0.02 & 0 & 0.05 & 13.28 & 100.28 \\
\hline " & 33.71 & 0.03 & 15.40 & 0.32 & 5.29 & 0.29 & 32.85 & 0.9 & 0.02 & 0.02 & 0.04 & 11.29 & 100.16 \\
\hline$"$ & 33.65 & 0.02 & 14.39 & 0.6 & 6.36 & 0.35 & 31.98 & 0.89 & 0.03 & 0.02 & 0.04 & 11.62 & 99.95 \\
\hline$"$ & 38.59 & 0 & 11.74 & 0.66 & 7.31 & 0.92 & 26.97 & 1.86 & 0.17 & 0 & 0 & 12.09 & 100.31 \\
\hline " & 41.07 & 0 & 10.45 & 0.83 & 6.65 & 0.81 & 28.84 & 1.87 & 0.16 & 0 & 0.01 & 10.06 & 100.75 \\
\hline$"$ & 36.37 & 0 & 13.92 & 1.01 & 7.26 & 0.94 & 26.87 & 1.8 & 0.19 & 0 & 0.01 & 11.51 & 99.88 \\
\hline$"$ & 43.56 & 0.01 & 0.84 & 0.01 & 12.90 & 0.07 & 34.03 & 0.31 & 0.01 & 0.03 & 0 & 8.39 & 100.16 \\
\hline$"$ & 37.31 & 0.01 & 3.67 & 0.06 & 25.91 & 0.12 & 20.74 & 0.73 & 0.02 & 0 & 0.01 & 11.71 & 100.29 \\
\hline$"$ & 40.15 & 0.01 & 1.06 & 0.02 & 25 & 0.13 & 23.72 & 0.61 & 0 & 0 & 0 & 10.17 & 100.87 \\
\hline " & 31.25 & 0.01 & 12.84 & 0.60 & 29.82 & 0.1 & 13.55 & 1.29 & 0.04 & 0.01 & 0.030 & 10.84 & 100.24 \\
\hline$"$ & 39.30 & 0 & 1.50 & 0.05 & 28.40 & 0.17 & 20.34 & 0.64 & 0.01 & 0.02 & 0.01 & 10.11 & 100.55 \\
\hline " & 29.82 & 0.02 & 13.13 & 0.63 & 29.87 & 0.1 & 13.99 & 1.22 & 0.04 & 0.01 & 0.01 & 11.76 & 100.60 \\
\hline Talc & 56.57 & 0.01 & 0.65 & 4.34 & 3.25 & 0.31 & 31.80 & 1.72 & 0.11 & 0.03 & 0 & & 98.79 \\
\hline " & 60.12 & 0 & 0.57 & 1.67 & 1.82 & 0.09 & 31.31 & 1.08 & 0.05 & 0.14 & 0.01 & & 96.86 \\
\hline$"$ & 61.33 & 0 & 0.56 & 1.86 & 2.06 & 0.11 & 30.28 & 0.52 & 0.08 & 0.14 & 0.01 & & 96.95 \\
\hline$"$ & 57.56 & 0 & 0.50 & 2.87 & 3.07 & 0.32 & 28.70 & 2.47 & 0.09 & 0.04 & 0 & & 95.62 \\
\hline " & 56.65 & 0 & 0.22 & 3.98 & 2.98 & 0.23 & 26.41 & 2.46 & 0.20 & 0.01 & 0.01 & & 93.15 \\
\hline$"$ & 54.37 & 0 & 0.83 & 4.56 & 3.62 & 0.43 & 29.13 & 0.52 & 0.10 & 0.01 & 0.01 & & 93.58 \\
\hline$"$ & 60.19 & 0.01 & 0.39 & 1.62 & 1.82 & 0.09 & 29.91 & 0.79 & 0.02 & 0.12 & 0.01 & & 94.97 \\
\hline$"$ & 61.64 & 0.02 & 0.47 & 1.11 & 1.40 & 0.07 & 31.07 & 0.44 & 0.04 & 0.04 & 0.01 & & 96.31 \\
\hline$"$ & 58.25 & 0.01 & 0.52 & 3.41 & 2.45 & 0.14 & 31.66 & 1.00 & 0.09 & 0.10 & 0.02 & & 97.65 \\
\hline$"$ & 60.06 & 0 & 0 & 0.75 & 4.86 & 0.07 & 29.44 & 0.20 & 0.04 & 0.06 & 0.04 & & 95.52 \\
\hline$"$ & 61.75 & 0 & 0.01 & 0.80 & 3.00 & 0.09 & 23.39 & 0.19 & 0.07 & 0.03 & 0.04 & & 95.37 \\
\hline$"$ & 60.58 & 0 & 0.01 & 0.30 & 4.17 & 0.08 & 20.61 & 0.29 & 0.04 & 0.01 & 0.03 & & 86.13 \\
\hline$"$ & 60.86 & 0 & 0.02 & 0.74 & 3.61 & 0.08 & 29.19 & 0.44 & 0.06 & 0.08 & 0.05 & & 95.13 \\
\hline$"$ & 62.34 & 0 & 0.01 & 0.55 & 4.20 & 0.11 & 29.93 & 0.30 & 0.06 & 0.07 & 0.05 & & 97.62 \\
\hline
\end{tabular}


Table 3. (Contd.)

\begin{tabular}{|c|c|c|c|c|c|c|c|c|c|c|c|c|c|}
\hline \multirow{2}{*}{ Mineral } & \multicolumn{12}{|c|}{ Chemical composition, wt \% } & \multirow{2}{*}{ Total } \\
\hline & $\mathrm{SiO}_{2}$ & $\mathrm{TiO}_{2}$ & $\mathrm{Cr}_{2} \mathrm{O}_{3}$ & $\mathrm{Al}_{2} \mathrm{O}_{3}$ & $\mathrm{FeO}$ & $\mathrm{MnO}$ & $\mathrm{MgO}$ & $\mathrm{NiO}$ & $\mathrm{CaO}$ & $\mathrm{Na}_{2} \mathrm{O}$ & $\mathrm{K}_{2} \mathrm{O}$ & $\mathrm{H}_{2} \mathrm{O}$ & \\
\hline \multirow{2}{*}{$\begin{array}{l}\text { Stilp- } \\
\text { nomelane }\end{array}$} & 48.57 & 0 & 0.05 & 4.90 & 30.85 & 0.25 & 6.64 & 0 & 0.34 & 0.01 & 0.78 & & 92.39 \\
\hline & 49.81 & 0 & 0.05 & 4.71 & 30.91 & 0.28 & 6.51 & 0.01 & 0.27 & 0 & 0.89 & & 93.44 \\
\hline$"$ & 47.90 & 0.01 & 0.11 & 5.42 & 31.02 & 0.29 & 6.35 & 0.09 & 0.11 & 0.08 & 1.94 & & 93.32 \\
\hline$"$ & 47.33 & 0.01 & 0.03 & 6.11 & 30.64 & 0.27 & 6.42 & 0.34 & 0.07 & 0.05 & 0.98 & & 92.25 \\
\hline$"$ & 51.11 & 0 & 0.01 & 4.15 & 27.73 & 0.25 & 9.31 & 0.08 & 0.03 & 0.03 & 1.96 & & 94.66 \\
\hline " & 46.84 & 0 & 0 & 4.52 & 29.79 & 0.31 & 6.11 & 0.02 & 0.11 & 0.11 & 5.34 & & 93.15 \\
\hline$"$ & 50.25 & 0.01 & 0.01 & 5.61 & 20.14 & 2.35 & 11.58 & 0.30 & 0.14 & 0 & 1.17 & & 91.56 \\
\hline " & 52.19 & 0 & 0.02 & 5.85 & 20.15 & 2.23 & 12.02 & 0.43 & 0.14 & 0.03 & 1.38 & & 94.44 \\
\hline " & 50.92 & 0 & 0.03 & 5.72 & 20.25 & 2.39 & 11.93 & 0.31 & 0.13 & 0.02 & 0.90 & & 92.60 \\
\hline$"$ & 51.77 & 0 & 0 & 5.86 & 20.52 & 2.51 & 12.19 & 0.50 & 0.14 & 0 & 0.50 & & 93.99 \\
\hline$"$ & 52.32 & 0 & 0 & 5.93 & 21.36 & 2.40 & 12.21 & 0.57 & 0.11 & 0.05 & 0.30 & & 95.25 \\
\hline " & 51.10 & 0 & 0 & 5.69 & 21.52 & 2.31 & 11.33 & 0.56 & 0.13 & 0.05 & 0.12 & & 92.81 \\
\hline$"$ & 51.20 & 0 & 0.01 & 6.00 & 20.59 & 1.97 & 12.93 & 0.81 & 0.34 & 0.01 & 0.05 & & 93.91 \\
\hline$"$ & 48.90 & 0 & 0.04 & 5.01 & 22.10 & 2.95 & 10.40 & 1.89 & 0.07 & 0.03 & 2.38 & & 93.77 \\
\hline$"$ & 51.04 & 0 & 0.30 & 4.23 & 20.30 & 1.84 & 12.13 & 2.47 & 0.36 & 0.32 & 0.79 & & 93.78 \\
\hline$"$ & 45.90 & 0 & 0.31 & 6.88 & 18.96 & 1.80 & 9.75 & 2.71 & 0.80 & 0.81 & 1.22 & & 89.14 \\
\hline$"$ & 46.68 & 0.01 & 0.06 & 4.61 & 21.12 & 2.51 & 9.82 & 1.92 & 0.13 & 0.02 & 4.12 & & 91.00 \\
\hline Calcite & 3.35 & 0 & 0 & 0.08 & 0.34 & 0.28 & 1.49 & 0.19 & 50.72 & 0.46 & 0.01 & & 56.92 \\
\hline$"$ & 3.79 & 0.02 & 0.03 & 0.04 & 0.89 & 0.30 & 1.72 & 0.29 & 49.34 & 0.55 & 0.01 & & 56.98 \\
\hline$"$ & 3.61 & 0.01 & 0.01 & 0.06 & 0.51 & 0.35 & 1.60 & 0.25 & 51.20 & 0.42 & 0.01 & & 58.03 \\
\hline$"$ & 3.90 & 0.03 & 0.02 & 0.07 & 0.75 & 0.42 & 1.87 & 0.33 & 50.53 & 0.67 & 0.01 & & 58.60 \\
\hline
\end{tabular}

chromite grains varying from euhedral to anhedral in shape were identified. Their compositions do not differ from the standard grains analyzed elsewhere. In some of these samples, sporadic sulfide grains (mainly pyrite and rarely millerite) were found.

\section{DISCUSSION}

The formation of $\mathrm{Fe}-\mathrm{Ni}$ ore at the Ržanovo deposit is closely related to the erosion and redeposition of the lateritic weathering crust after Jurassic ultramafic rocks. The primary laterites are retained only as relics in serpentinites. No lateritic material with clastic structure, known at other $\mathrm{Fe}-\mathrm{Ni}$ deposits in the Vardar Zone, is at the Ržanovo deposit. The laterites were formed at this deposit and other deposits nearby under stable conditions without supply of coarse clastic material (Ivanov, 1965), so that laterites were not diluted in the process of chemical and mechanical redeposition. Resistant chromites and most rock-forming minerals were deposited in the process of mechanical migration, whereas sulfides were redeposited as products of chemical reactions.

Deposition of $\mathrm{Fe}-\mathrm{Ni}$ minerals was closely related to variations in the redox potential of seawater, as well as in $\mathrm{pH}$. The majority of $\mathrm{Fe}$ - and Ni-bearing ore minerals (hematite, magnetite, limonite, pyrite) were formed in the course of sedimentation as indicated by the oolitic structure of ore with clearly discernible ovoids of magnetite, hematite, and other minerals (Figs. 6, 9).

The occurrence or absence of pisolites and oolites in various parts of the Ržanovo orebody shows that the depth of the marine basin varied during the deposition of sedimentary ore. In the shallow sea, the conditions favored the formation of oolites and pisolites under the action of waves. Massive ores were deposited under quiet conditions in the deeper marine basin. The cores of oolites are commonly composed of magnetite, which is coated with maghemite, hematite, and other shells. It is important that silica was largely deposited as isolated jasper lenses varying in size. Jasper almost always contains about $0.4 \% \mathrm{Ni}$, which clearly points to its origin as a result of lateritic weathering crust breakdown.

Thus, the formation of typical nontronite lateritic weathering mantle lasted from the onset of the Early Cretaceous to its end (Albian). The subsequent erosion of the nontronite lateritic weathering mantle and transport of the material into sedimentary basins was 
Table 4. Chemical composition of major ore minerals from Ržanovo deposit, results of microprobe analysis

\begin{tabular}{|c|c|c|c|c|c|c|c|c|c|c|c|c|}
\hline \multirow{2}{*}{ Mineral } & \multicolumn{11}{|c|}{ Chemical composition, wt $\%$} & \multirow{2}{*}{ Total } \\
\hline & $\hat{I}$ & $\mathrm{Mg}$ & $\mathrm{Al}$ & $\mathrm{Ti}$ & $\mathrm{V}$ & $\mathrm{Cr}$ & Mn & $\mathrm{Fe}$ & Co & $\mathrm{Ni}$ & $\mathrm{Zn}$ & \\
\hline Chromit & 32.35 & 5.68 & 5.68 & 0.03 & 0.17 & 40.34 & 5.40 & 10.23 & 0.61 & 0 & 0.49 & 100.98 \\
\hline$"$ & 32.24 & 5.25 & 5.74 & 0.02 & 0.15 & 40.09 & 3.33 & 13.42 & 0.53 & 0 & 0.36 & 101.13 \\
\hline$"$ & 33.65 & 6.57 & 8.11 & 0.03 & 0.13 & 38.13 & 2.90 & 11.98 & 0.27 & 0.02 & 0.15 & 101.94 \\
\hline " & 33.28 & 5.97 & 8.42 & 0.03 & 0.12 & 38.16 & 3.06 & 10.74 & 0.37 & 0.03 & 0.24 & 100.42 \\
\hline$"$ & 33.30 & 5.48 & 8.50 & 0.03 & 0.14 & 37.53 & 6.19 & 8.63 & 1.07 & 0.03 & 0.45 & 101.35 \\
\hline$"$ & 30.87 & 3.09 & 4.15 & 0.03 & 0.07 & 40.33 & 8.55 & 12.73 & 0.46 & 0.23 & 0.53 & 101.5 \\
\hline " & 32.06 & 3.63 & 8.46 & 0.01 & 0.17 & 33.38 & 7.94 & 13.25 & 0.66 & 0.20 & 1.07 & 100.82 \\
\hline$"$ & 33.85 & 4.70 & 8.65 & 0.02 & 0.17 & 38.67 & 0.79 & 13.20 & 0.01 & 0.04 & 0.14 & 99.25 \\
\hline$"$ & 32.36 & 5.70 & 5.97 & 0.05 & 0.06 & 40.46 & 1.60 & 13.94 & 0.19 & 0.02 & 0.13 & 100.47 \\
\hline$"$ & 30.02 & 0.90 & 4.01 & 0.04 & 0.09 & 38.42 & 2.90 & 23.80 & 0.43 & 0.07 & 0.91 & 101.60 \\
\hline$"$ & 32.17 & 4.24 & 5.90 & 0.04 & 0.09 & 40.49 & 4.22 & 12.96 & 1.11 & 0.05 & 0.36 & 101.63 \\
\hline$"$ & 33.12 & 4.98 & 7.72 & 0.01 & 0.22 & 37.57 & 0.85 & 17.76 & 0.10 & 0.05 & 0.27 & 102.66 \\
\hline$"$ & 31.95 & 5.12 & 5.83 & 0.08 & 0.13 & 39.56 & 1.31 & 15.74 & 0.22 & 0.03 & 0.25 & 100.17 \\
\hline Magnetite & 20.60 & 0.10 & 0.05 & 0 & 0 & 2.70 & 0.33 & 65.56 & 0 & 1.28 & 0.06 & 90.69 \\
\hline$"$ & 20.83 & 0.05 & 0.62 & 0.03 & 0 & 1.47 & 0.11 & 68.03 & 0 & 0.08 & 0.03 & 91.26 \\
\hline$"$ & 20.31 & 0.16 & 0.37 & 0.05 & 0 & 1.58 & 0.17 & 66.44 & 0 & 0.10 & 0 & 89.18 \\
\hline " & 20.72 & 0.01 & 0.01 & 0 & 0.01 & 0.74 & 0.15 & 70.39 & 0.02 & 0.56 & 0 & 92.58 \\
\hline " & 20.65 & 0.08 & 0.40 & 0.03 & 0 & 1.54 & 0.02 & 68.01 & 0.06 & 0.05 & 0 & 90.79 \\
\hline " & 20.67 & 0.04 & 0.28 & 0.04 & 0 & 1.44 & 0.07 & 68.64 & 0 & 0.06 & 0.03 & 91.27 \\
\hline$"$ & 20.37 & 0.22 & 0.32 & 0.04 & 0 & 1.53 & 0.06 & 66.84 & 0 & 0.18 & 0.01 & 89.57 \\
\hline$"$ & 20.82 & 0.44 & 0.62 & 0.05 & 0 & 1.70 & 0.10 & 66.50 & 0 & 0.27 & 0.01 & 90.51 \\
\hline$"$ & 20.52 & 0.01 & 0 & 0 & 0.01 & 0.48 & 0.21 & 69.81 & 0 & 0.78 & 0.03 & 91.85 \\
\hline$"$ & 20.97 & 0.02 & 0.06 & 0 & 0 & 3.06 & 0.39 & 66.23 & 0 & 1.40 & 0.04 & 92.21 \\
\hline$"$ & 21.49 & 0.09 & 0.23 & 0 & 0.02 & 6.87 & 1.79 & 59.56 & 0 & 1.41 & 0.17 & 91.71 \\
\hline$"$ & 21.46 & 1.17 & 0.96 & 0.03 & 0 & 1.24 & 0.10 & 66.63 & 0 & 0.34 & 0.01 & 92.00 \\
\hline Hematite & 20.36 & 0.05 & 0.04 & 0.01 & 0 & 0.31 & 0.03 & 70.21 & 0 & 0.03 & 0 & 91.05 \\
\hline$"$ & 20.19 & 0 & 0 & 0.06 & 0 & 0.10 & 0.01 & 70.11 & 0 & 0.02 & 0.01 & 90.50 \\
\hline$"$ & 20.32 & 0 & 0 & 0.03 & 0 & 0.14 & 0.00 & 70.60 & 0 & 0 & 0.00 & 91.10 \\
\hline " & 20.11 & 0.01 & 0.01 & 0.02 & 0 & 0.06 & 0.01 & 69.95 & 0 & 0.01 & 0.01 & 90.20 \\
\hline$"$ & 20.33 & 0.31 & 0.39 & 0.03 & 0 & 0.23 & 0.02 & 68.55 & 0 & 0.05 & 0.01 & 89.92 \\
\hline$"$ & 20.02 & 0.01 & 0.03 & 0.01 & 0 & 0.09 & 0.04 & 69.52 & 0 & 0.02 & 0 & 89.74 \\
\hline$"$ & 20.29 & 1.47 & 0.26 & 0.01 & 0.01 & 0.29 & 0.18 & 65.80 & 0 & 0.17 & 0 & 88.48 \\
\hline$"$ & 19.74 & 0.72 & 0.07 & 0.03 & 0.00 & 0.17 & 0.16 & 66.39 & 0 & 0.13 & 0.01 & 87.44 \\
\hline$"$ & 20.19 & 0.11 & 0.09 & 0.03 & 0.00 & 0.98 & 0.02 & 68.23 & 0 & 0.06 & 0 & 89.71 \\
\hline$"$ & 20.23 & 0.05 & 0.07 & 0.03 & 0.00 & 0.86 & 0.04 & 68.73 & 0 & 0.03 & 0.02 & 90.07 \\
\hline$"$ & 20.08 & 0.05 & 0.22 & 0.05 & 0.00 & 1.28 & 0 & 67.09 & 0 & 0.04 & 0 & 88.80 \\
\hline
\end{tabular}



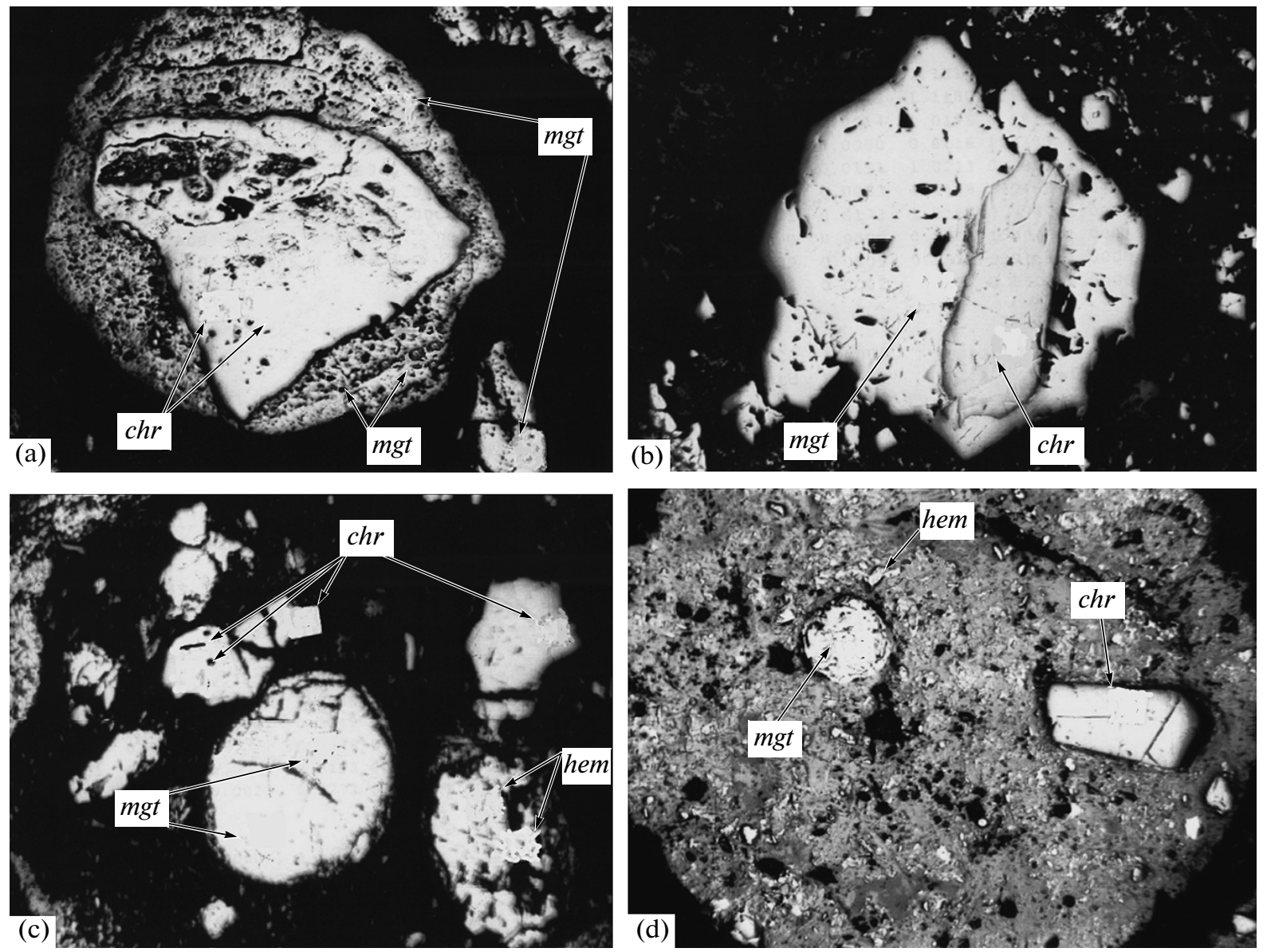

Fig. 9. Photomicrographs of major mineral aggregates in oolitic ore of Ržanovo Fe-Ni deposit: (a, b) chromite cores of magnetite ooliths; (c, d) magnetite ooliths without chromite cores.

completed before deposition of Albian-Cenomanian limestones.

It should be noted that supply of material from primary lateritic weathering mantles was not a continuous process. During some periods, a large amount of the material was brought into the basin from other sources. The samples with elevated contents of trace elements are unrelated to ultramafic rocks. Such dilution of primary lateritic material resulted in depletion of particular segments of the orebody in nickel.

The deposition of carbonate sediments and diagenesis of redeposited material took place in AlbianCenomanian. During diagenesis and epigenesis, the primary minerals had been altered and new minerals, e.g., hematite, magnetite, millerite, pyrite, chlorite, and mixed-layer minerals were formed. The surrounding medium was enriched in $\mathrm{Ni}$, which was supplied from weathering mantle in form of $\mathrm{Ni}$ hydrocarbonate. In the Late Cretaceous, Eocene, and later on, the Ržanovo deposit was subject to dynamometamorohism. As a result, sedimentary rocks were transformed into the low-temperature metamorphic rocks comprising the following minerals: magnetite, hematite, stilpnomelan, chlorite, talc, magnesioriebeckite, albite, calcite, and dolomite (Boev and Jankovich, 1996). These minerals do not always occur together.

No thoroughly studied counterparts of the Ržanovo deposit were revealed in ophiolitic belts in Russia and CIS countries, although a geodynamic and metallogenic setting similar to that in the Balkans existed in the southern Urals and central Kazakhstan (Puchkov 2000; Bekzhanov et al., 2004; Salikhov et al., 2004), in the eastern Eurasian continent (Stepanov, 2009), and in the Caucasus (Satian, 1984). Future world nickel market opportunities look favorable because of growing metal consumption in the Asia-Pacific region, primarily China, India, Europe, and CIS countries (Igrevskaya, 2006). Therefore, interest in nickel deposits will only increase in the future.

The study of the Ržanovo deposit shows that in addition to the endogenic $\mathrm{Cu}-\mathrm{Ni}$ deposits related to magmatic mafic and ultramafic rocks and exogenic $\mathrm{Ni}$-silicate deposits hosted in lateritic weathering mantles after serpentinites, a third independent group of metamorphosed $\mathrm{Fe}-\mathrm{Ni}$ redeposited lateritic ores has been recognized.

In the future, investigation of PGE, $\mathrm{Au}$, and $\mathrm{Ag}$ distribution in metamorphosed $\mathrm{Fe}-\mathrm{Ni}$ redeposited 
lateritic ores will be of practical interest. Information on elevated concentrations of these noble metals in $\mathrm{Ni}$-silicate deposits have repeatedly appeared in the literature over the last 15 years (Talovina, 2012).

\section{CONCLUSIONS}

The Ržanovo $\mathrm{Fe}-\mathrm{Ni}$ deposit is a typical example of metamorphosed lateritic ore redeposited in sedimentary basins. A continuous ore layer with rather homogeneous structure was formed at this deposit during Late Cretaceous lateritic weathering. The most important economic types of ore are fissile hematite and massive magnetite ores. The major Ni-bearing minerals are magnetite, hematite, chromite, sulfides, talc, chlorite, amphibole, and stilpnomelan. The occurrence of sulfide in ore at the Ržanovo deposit shows that reductive conditions and variable $\mathrm{pH}$ were characteristic of ore deposition. Oolites and pisolites were deposited in the shallow-water marine basin, and massive ores were deposited in a deeper marine basin. The Alpine tectonics resulted in deformation and metamorphism of ore and overturning of the orebody, which currently dips almost vertically.

The considered data clearly show that metamorphosed $\mathrm{Fe}-\mathrm{Ni}$ redeposited lateritic ores are undoubtedly controlled by ophiolitic belts. This implies that the ophiolitic complexes known in Russia, e.g., in the Urals, eastern Sayan, the Caucasus, the KoryakiaKamchatka region, and other territories, merit estimating the discovery prospects of such deposits.

\section{ACKNOWLEDGMENTS}

This study was supported by the Russian Foundation for Basic Research (project no. 12-05-00443-a).

\section{REFERENCES}

Bekzhanov, G.R., Kamensky, A.S, and Kantemirov, M.D., Silicate nickel deposits of Kazakhstan and Outlook for their development, Geol. Okhrana Nedr, 2004, no. 2, pp. 38-46. Boev, B., Metamorphism of the Ržanovo-Studena Voda ore series, Master Thesis, Belgrade: Faculty of Mining and Geology, University of Belgrade, 1982.

Boev, B. and Jankovic, S., Nickel and nickelferous iron deposits of the Vardar Zone (SE Europe) with particular reference to the Ržanovo-Studena Voda ore-bearing series, in Faculty of Mining and Geology-Štip, St. Cyril and Methodius University, Special issue, Skopje, 1996, no. 3, pp. 270-278.

Boev, B. and Lepitkova, S., Quantitative mineralogical analysis of ore from the Ržanovo iron-nickel-bearing deposit, XXIV October counseling of miners and metallurgists, Donji Milanovac, 1994, pp. 24-26.

Boev, B. and Serafimovski, T., Composition of major mineral phases within the products of prereduction of nickelbearing ores from the Ržanovo deposit, Macedonia, in XXIV October counseling of miners and metallurgists, Bor, 1992, pp. 56-59.

Boev, B. and Serafimovski, T., Types of lateritic weathering crust along the Vardar River, Republic of Macedonia, in Symposium on Teranes of Serbia, Belgrade, 1996, pp. 427-432.
Boev, B. and Stojanov, R., Metamorphism of Ni-Fe ores from Ržanovo-Studena Voda and the Zone Almopias, Geol. Macedonica, 1985, vol. 1, pp. 191-194.

Dilek, Y. and Thy, P., Island arc tholeiite to boninitic melt evolution of the Cretaceous Kizildag (Turkey) ophiolite: model for multistage early arc-forearc magmatism in Tethyan subduction factories, Lithos, 2009, vol. 113, nos. $1 / 2$, pp. 68-87.

Igrevskaya, L.V., Contemporary development of the world nickel industry, Mineral'nye resursy Rossii. Ekonomika $i$ upravlenie, 2006, no. 1, pp. 96-99.

Ivanov, T., Iron-nickel bearing ore Ržanovo at Kozif Mountain, Macedonia, in Proceedings of the 3rd Congress of Geologists of Yugoslavia, Budva, 1962, vol. 2, pp. 249-264.

Ivanov, T., Metallogeny of the southern part of the Vardar Zone, Doctoral Thesis, Belgrade: Faculty of Mining and Geology, University of Belgrade, 1965.

Ivanov, T., Misar, Z., Bowes, D.R., et al., The Demir Kapija-Gevgelija ophiolite massif, Macedonia, Yugoslavia, Ofioliti, 1987, vol. 12, no. 3, pp. 457-478.

Maksimovic, Z., Types of the fossil weathering of ultramafic rocks in SE Europe, Bull. Serb. Acad. Sci. Nat. Math., 1981, vol. 75, no. 21, pp. 13-26.

Maksimovic, Z. and Panto, G., The main nickel bearing phases in the Ržanovo deposit, Yugoslavia: chlorite, talc, stilpnomelan, and magnesioribeckite, Bull. Serb. Acad. Sci., Nat. Math., 1982, vol. 72, no. 23, pp. 77-96.

Puchkov, V.N., Paleogeodinamika Yuzhnogo i Srednego Urala (Paleodynamics of the Southern and Central Urals), Ufa: Dauriya, 2000.

Robertson, H.F., Contrasting modes of ophiolite emplacement in the eastern Mediterranean region, Geol. Soc. London Mem., 2006, vol. 32, pp. 235-261.

Robertson, A., Karamata, S., and Saric, K., Overview of ophiolites and related units in the Late Palaeozoic-Early Cenozoic magmatic and tectonic development of Tethys in the northern part of the Balkan region. Ophiolites and related geology of the Balkan region, Lithos, 2009, vol. 108, nos. 1/4, pp. 1-36.

Salikhov, D.N., Zakharov, O.A., Belikova, G.I., et al., Poleznye iskopaemye Respubliki Bashkortostan (nikel' $i$ kobal't) (Mineral resources of Republic of Bashkortostan: nickel and cobalt), Ufa: Gilem, 2004.

Satian, M.A., Ofiolitovye Progiby Mezotetisa (Ophiolitic troughs of Mesotethys), Yerevan, AN ArmSSR, 1984.

Stepanov, V.A., Copper-nickel deposits in the eastern Eurasia: a review, Vestnik KRAUNTS, Nauki o Zemle, 2009, vol. 1 , no. 13, pp. 139-149.

Talovina, I.V., Geokhimiya ural'skikh oksidno-silikatnykh nikelevykh mestorozhdenii (Geochemistry of oxide-silicate nickel deposits in the Urals), St. Petersburg: Gorny National University of Mineral Resources, 2012.

Zagorchev, I., Balica, C., Balintoni, I., et al., Palaeozoic evolution of the Ograzhden Unit (Serbo-Macedonian Massif, Bulgaria and Macedonia), Proceedings Book: Second Congress of Geologists of the Republic of Macedonia, Krusevo, 2012, pp. 13-16.

Zagorchev, I., Dabovski, C., and Dumurdzhanov, N., Tectonic structure of Bulgaria and Macedonia based on TRANSMED TRANSECT III, in Proceedings Book: First Congress of Geologists of the Republic of Macedonia, Ohrid, 2008, pp. 503-510.

Translated by V. Popov 